\title{
Estimated desert-dust ice nuclei profiles from polarization lidar: methodology and case studies
}

\author{
R. E. Mamouri ${ }^{1}$ and A. Ansmann ${ }^{2}$ \\ ${ }^{1}$ Cyprus University of Technology, Dept. of Civil Engineering and Geomatics, Limassol, Cyprus \\ ${ }^{2}$ Leibniz Institute for Tropospheric Research, Leipzig, Germany \\ Correspondence to: R. E. Mamouri (rodanthi.mamouri@cut.ac.cy)
}

Received: 4 August 2014 - Published in Atmos. Chem. Phys. Discuss.: 13 October 2014

Revised: 4 March 2015 - Accepted: 5 March 2015 - Published: 30 March 2015

\begin{abstract}
A lidar method is presented that permits the estimation of height profiles of ice nuclei concentrations (INC) in desert dust layers. The polarization lidar technique is applied to separate dust and non-dust backscatter and extinction coefficients. The desert dust extinction coefficients $\sigma_{\mathrm{d}}$ are then converted to aerosol particle number concentrations $\mathrm{APC}_{280}$ which consider particles with radius $>280 \mathrm{~nm}$ only. By using profiles of $\mathrm{APC}_{280}$ and ambient temperature $T$ along the laser beam, the profile of INC can be estimated within a factor of 3 by means of APC- $T$-INC parameterizations from the literature. The observed close relationship between $\sigma_{\mathrm{d}}$ at $500 \mathrm{~nm}$ and $\mathrm{APC}_{280}$ is of key importance for a successful INC retrieval. We studied this link by means of AERONET (Aerosol Robotic Network) sun/sky photometer observations at Morocco, Cabo Verde, Barbados, and Cyprus during desert dust outbreaks. The new INC retrieval method is applied to lidar observations of dust layers with the spaceborne lidar CALIOP (Cloud Aerosol Lidar with Orthogonal Polarization) during two overpasses over the EARLINET (European Aerosol Research Lidar Network) lidar site of the Cyprus University of Technology (CUT), Limassol ( $34.7^{\circ} \mathrm{N}$, $\left.33^{\circ} \mathrm{E}\right)$, Cyprus. The good agreement between the CALIOP and CUT lidar retrievals of $\sigma_{\mathrm{d}}, \mathrm{APC}_{280}$, and INC profiles corroborates the potential of CALIOP to provide 3-D global desert dust $\mathrm{APC}_{280}$ and INC data sets.
\end{abstract}

\section{Introduction}

The evolution of the ice phase in initially liquid-water clouds is still poorly understood and thus not well considered in climate models. Trustworthy predictions of the overall indi- rect aerosol effect on climate are impossible as long as the important branch of heterogeneous ice formation, the subsequent production of rain, and the associated removal of water from the atmosphere are not properly described in atmospheric circulation models. Aircraft-based field campaigns in cloudy environments are performed to improve the basic process understanding of heterogeneous ice formation under given meteorological and aerosol conditions. Laboratory studies and in situ aerosol characterization provide important knowledge on the influence of a variety of natural and anthropogenic aerosol types on cloud glaciation. Lidar- and radar-based remote sensing allows for a continuous monitoring of co-occurring aerosol and cloud fields in their natural environment and thus a detailed study of the evolution of the ice phase in liquid and mixed-phase cloud layers and the impact of aerosol layers on these processes.

Ground-based active remote sensing is, in general, of great importance for observational studies of aerosol-cloud interactions because of its unique potential to observe aerosol layers and clouds (from base to top) with high vertical and temporal resolution and this over long time periods (Ansmann et al., 2005, 2009; Illingworth et al., 2007; Seifert et al., 2010; Martucci and O'Dowd, 2011; de Boer et al., 2011; Kanitz et al., 2011; Wandinger et al., 2012; Bühl et al., 2013; Schmidt et al., 2014). Continuously running stations can provide dense aerosol-cloud data sets for statistical analysis for all seasons of the year. Organized in networks, regional aspects regarding aerosol conditions (varying mixtures of urban haze, biogenic aerosols, smoke, marine and dust particles), and orographic and meteorological influences can be studied in large detail. 
However, further efforts are required to improve the retrieval capabilities of lidar-radar supersites. Regarding heterogeneous ice formation, it is of interest to explore the potential of polarization lidar to deliver height profiles of ice nuclei concentration (INC) up to cloud base as well as around and above cloud layers. Such an INC profiling would open new ways to explore the evolution of mixed-phase clouds and the role of aerosols in this context. Applied to spaceborne CALIOP (Cloud Aerosol Lidar with Orthogonal Polarization) observations, such an INC retrieval technique could help to establish global 3-D maps of INC. CALIOP is part of the CALIPSO (Cloud-Aerosol Lidar and Infrared Pathfinder Satellite Observation) mission (Winker et al., 2009).

A first attempt to use particle optical properties measured with lidar for an INC estimation was undertaken during the Saharan Mineral Dust Experiment (SAMUM) in May-June 2006 (Ansmann et al., 2008). Based on Aerosol Robotic Network (AERONET) photometer observations of optical and microphysical dust properties it was demonstrated that the retrieval of the particle number concentration $\mathrm{APC}_{250}$ of large desert dust particles with radius $r>250 \mathrm{~nm}$ from lidar profiles of the dust extinction coefficient $\sigma_{\mathrm{d}}$ measured at $532 \mathrm{~nm}$ wavelength is possible with good accuracy. This is an essential prerequisite for the next step, the estimation of INC. The large particle fraction is assumed to be the reservoir for most favorable ice nuclei (DeMott et al., 2006, 2010). However, to estimate INC from $\mathrm{APC}_{250}$ in observed dust layers, a rather crude assumption about the ratio of $\mathrm{APC}_{250}$ to INC of $30 \pm 20$ was used in this first, preliminary approach of Ansmann et al. (2008).

After the eruption of the Icelandic volcano Ejyafjallajökull in April 2010, Seifert et al. (2011) investigated the role of volcanic particles to serve as ice nuclei and continued the discussion regarding the relationship between the particle extinction coefficient, number concentration $\mathrm{APC}_{250}$ and INC in the case of volcanic particles, which were found to be very efficient ice nuclei. The authors used the same parameterization to obtain $\mathrm{APC}_{250}$ from the lidar-derived $\sigma_{\mathrm{d}}$ values as Ansmann et al. (2008) for desert dust and also applied very rough assumptions about the ratio of $\mathrm{APC}_{250}$ to INC to provide estimates for INC in the case of volcanic aerosol layers.

The recently published INC-APC 250 parameterization schemes (DeMott et al., 2010, 2015) motivated us to intensify our effort to develop a quantitative lidar-based method for INC profiling. These parameterizations are developed for immersion freezing which is the most important heterogeneous ice nucleation mechanism (Ansmann et al., 2008; de Boer et al., 2011; Murray et al., 2012). They are applicable to desert dust (DeMott et al., 2015) and, more general, also to not well defined aerosol types (DeMott et al., 2010).

In this paper, we start with an INC retrieval scheme for desert dust. Mineral dust from desert areas belongs to the most important aerosol components in the atmosphere regarding heterogeneous ice formation (Richardson et al., 2007; Kamphus et al., 2010; Murray et al., 2012; Cziczo et al., 2013; DeMott et al., 2015). Desert dust particles are advantageous for the following reasons: as mentioned, for a successful lidar-based INC retrieval a clear relationship between the lidar-derived extinction coefficient $\sigma_{\mathrm{d}}$ and the particle number concentration $\mathrm{APC}_{250}$ is of key importance. Such a close correlation is given for desert dust because desert dust particles always show a pronounced bimodal volume size distribution consisting of a fine mode (particles with $r<500 \mathrm{~nm}$ ) and a pronounced coarse mode (particles with $r>500 \mathrm{~nm}$ ). This feature significantly facilitates the $\mathrm{APC}_{250}$ retrieval and subsequent INC estimation as will be discussed in Sect 3. The correlation study in Sect. 3 is based on several combined lidar and AERONET photometer data sets collected during the two desert dust SAMUM campaigns in Morocco (SAMUM-1, 2006; Heintzenberg, 2009) and Cabo Verde (SAMUM-2, 2008; Ansmann et al., 2011) and the Saharan Aerosol Long-range Transport and Aerosol-CloudInteraction Experiment (SALTRACE; Ansmann et al., 2014) conducted in Barbados in the summer of 2013. Furthermore, we include a 4-year AERONET data set collected at Limassol, Cyprus, in our investigation of the relationship between dust extinction and the number concentration of large dust particles. Cyprus is frequently crossed by major desert dust outbreaks from the Sahara and the Middle East deserts (Nisantzi et al., 2015). For the sake of simplicity (see Sect. 3) we will use $\mathrm{APC}_{280}$ (number concentration of particles with $r>280 \mathrm{~nm}$ ) in our study instead of $\mathrm{APC}_{250}$ which was introduced by DeMott et al. (2006).

After a short introduction into the instrumentation, field activities and auxiliary meteorological data in Sect. 2, the INC retrieval method is explained in Sect. 3. Section 4 contains applications of the new INC retrieval scheme to CALIOP observations performed during overpasses over the European Aerosol Research Lidar Network (EARLINET) station of Limassol, Cyprus. The CALIOP and Limassol lidar results (optical properties, $\mathrm{APC}_{280}$, INC) are compared for a major and unique Saharan dust outbreak with dust layers of up to $10 \mathrm{~km}$ height and for another dust outbreak from the Middle East deserts. Summarizing and concluding remarks are given in Sect. 5.

\section{Instrumentation and auxiliary meteorological data}

\subsection{CUT lidar}

The lidar station of the Cyprus University of Technology (CUT) at Limassol $\left(34.7^{\circ} \mathrm{N}, 33^{\circ} \mathrm{E}, 50 \mathrm{~m}\right.$ a.s.l. $)$ is located about $150 \mathrm{~km}$ south of Turkey and $250 \mathrm{~km}$ west of Syria and belongs to EARLINET (Pappalardo et al., 2014). The lidar is described by Mamouri et al. (2013) and enables us to determine height profiles of the particle backscatter coefficient and particle linear depolarization ratio at $532 \mathrm{~nm}$.

In the analysis of the CUT lidar data as described in Sect. 3.1, actual height profiles of temperature and pres- 
sure profiles are required for the Limassol region. The operational systems GDAS (Global Data Assimilation System) of the National Weather Service's National Centers for Environmental Prediction (NCEP) provide these meteorological parameters. NOAA's Air Resources Laboratory (ARL, https://www.ready.noaa.gov/gdas1.php) NCEP model GDAS output archives contain basic meteorological fields for the horizontal wind components, temperature, and humidity for specific pressure levels.

\subsection{AERONET sun/sky photometer}

The EARLINET lidar site is co-located with an AERONET sun/sky photometer (AERONET, CUT-TEPAK site, Limassol, Cyprus, http://aeronet.gsfc.nasa.gov) (Holben et al., 1998; Mamouri et al., 2013; Nisantzi et al., 2015). The CUT AERONET photometer allows for the retrieval of AOT at eight wavelengths from 339 to $1638 \mathrm{~nm}$. Sky radiance observations at four wavelengths complete the AERONET observations. From these measurements the column-integrated particle size distribution is retrieved (Dubovik and King, 2000; Dubovik et al., 2006).

Further AERONET sun/sky photometer observations are used in our study. The measurements were conducted in the framework of SAMUM-1 close to the Sahara at the airport of Ouarzazate in southern Morocco in May and June 2006, of SAMUM-2 at the airport of Praia, the capital city of Cabo Verde, in the near range of the outflow regime of Saharan dust across the tropical Atlantic, in January and February 2008, and of SALTRACE at the Caribbean Institute for Meteorology and Hydrology on Barbados, in the far range of Saharan dust long-range transport across the Atlantic in June and July 2013, about $5000-8000 \mathrm{~km}$ west of the main dust sources. Details of these AERONET stations can be found on the AERONET web page (http://aeronet.nasa.gov), in Mamouri and Ansmann (2014) and Toledano et al. (2009, 2011). For these desert dust campaigns, lidar observations of dust layering are also available (Tesche et al., 2009b, 2011; Haarig et al., 2014).

\subsection{CALIOP}

The spaceborne lidar CALIOP is described by Winker et al. (2009). Numerous validation projects have been carried out (e.g., Mamouri et al., 2009) to demonstrate the capability of this lidar to provide accurate aerosol backscatter profiles throughout the troposphere. The spaceborne aerosol/cloud lidar measures polarization-sensitive backscatter signals at $532 \mathrm{~nm}$. CALIOP aerosol products include height profiles of the $532 \mathrm{~nm}$ particle backscatter coefficient, extinction coefficient, particle backscatter coefficient determined from the cross-polarized $532 \mathrm{~nm}$ signal channel, and the particle linear depolarization ratio. We use the CALIOP level 2 version 3 aerosol profile products. Besides the available profile of the particle depolarization ratio, we calculated this quantity in addition from the individual profiles of the crosspolarized and total $532 \mathrm{~nm}$ particle backscatter coefficients after smoothing of these individual profiles as suggested by Tesche et al. (2013).

For the CALIPSO level 2 aerosol profiles product, vertical profiles of the mean values of meteorological parameters along the flight track are also provided. These data are given for the midpoint of each range bin of the CALIOP profile. The meteorological parameters such as temperature, pressure, and relative humidity are derived from the Goddard Earth Observing System Model, Version 5 (GEOS-5) data product and are provided by the GMAO (Global Modeling and Assimilation Office) Data Assimilation System (http://gmao.gsfc.nasa.gov).

\subsection{HYSLPIT}

The data analysis includes a careful investigation of the air mass origin and long-range aerosol transport by means of backward trajectory analysis with the HYSPLIT (HYbrid Single-Particle Lagrangian Integrated Trajectory) model. Access is provided via the NOAA ARL READY website (http: //www.arl.noaa.gov/HYSPLIT.php). HYSPLIT is described in detail by Draxler and Hess $(1997,1998)$ and Draxler (1999).

\section{Method}

In this section, we present the INC retrieval scheme. The data analysis consists of three parts. In the first part (Sect. 3.1), height profiles of the particle backscatter coefficient are determined from the elastic backscatter lidar data. Afterwards, the polarization lidar technique is used to separate dust and non-dust backscatter fractions and to estimate the desert dust extinction coefficients $\sigma_{\mathrm{d}}$. The second part (Sect. 3.2) deals with the conversion of $\sigma_{\mathrm{d}}$ profiles into $\mathrm{APC}_{280}$ profiles. In this context, a comprehensive study of the relationship between $\sigma_{\mathrm{d}}$ and $\mathrm{APC}_{280}$ is presented, based on the AERONET observations mentioned above. This investigation demonstrates that an accurate determination of $\mathrm{APC}_{280}$ from $\sigma_{\mathrm{d}}$ is possible. The third part (Sect. 3.3) covers the conversion of $\mathrm{APC}_{280}$ to INC. Here we use the recently published parameterizations of DeMott et al. (2010, 2015), which are based on comprehensive laboratory studies and field campaigns conducted during the last 14 years. Table 1 provides an overview of all steps of the method. The different steps will now be explained in the following subsections.

\subsection{Part 1: Dust extinction from polarization lidar}

Figure 1 presents two examples of dust profiling with the CUT lidar at Limassol. The retrieval of the particle backscatter coefficient $\beta_{\mathrm{p}}$ at $532 \mathrm{~nm}$ (step 1 in Table 1) and particle linear depolarization ratio is discussed in detail by Mamouri et al. (2013) and Mamouri and Ansmann (2014). Fine-mode 
Table 1. The five steps required to obtain the dust-related INC profile from the profile of the particle backscatter coefficient $\beta_{\mathrm{p}}$ measured with polarization lidar. The determination of $\beta_{\mathrm{d}}$ and $\sigma_{\mathrm{d}}$ is explained in Sect. 3.1. In Sect. 3.2, the retrieval of the number concentration of large particles $\mathrm{APC}_{280}$ is described, and the INC estimation is finally outlined in Sect. 3.3.

\begin{tabular}{llll}
\hline Step & Computed parameter & & Reference \\
1 & Particle backscatter coefficient & $\beta_{\mathrm{p}}$ & Mamouri et al. (2013) \\
2 & Dust backscatter coefficient & $\beta_{\mathrm{d}}$ & Mamouri et al. (2013); Mamouri and Ansmann (2014) \\
3 & Dust extinction coefficient & $\sigma_{\mathrm{d}}$ & Mamouri et al. (2013); Mamouri and Ansmann (2014) \\
4 & Dust APC 280 & $n_{\mathrm{d}, 280}$ & Eq. (1) \\
5 & Dust INC & $n_{\mathrm{IN}}$ & Eq. (2), DeMott et al. (2010) \\
& & Eq. (3), DeMott et al. (2015) \\
\hline
\end{tabular}

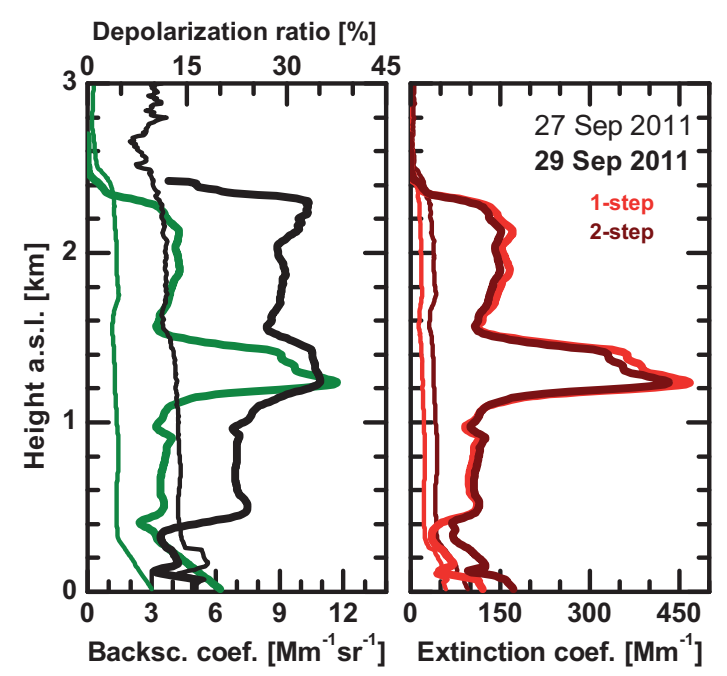

Figure 1. (Left) The $532 \mathrm{~nm}$ particle backscatter coefficient (green) and particle linear depolarization ratio (black) as a function of height above sea level (a.s.l.) and (right) dust extinction coefficients computed by means of the one-step and two-step methods (Mamouri and Ansmann, 2014). A major dust outbreak from the Middle East deserts was observed with the CUT lidar at Limassol, Cyprus, on 29 September 2011, whereas fine-mode soil dust, probably injected during biomass burning events in Turkey, was observed on 27 September 2011. The data analysis is explained in detail by Mamouri and Ansmann (2014).

soil dust dominated particle backscattering on 27 September 2011 in Fig. 1, while a major dust outbreak from the Middle East deserts was observed on 29 September 2011. The particle linear depolarization ratio at $532 \mathrm{~nm}$ is used to separate the non-dust backscatter coefficient from the dust backscatter coefficient $\beta_{\mathrm{d}}$ (step 2 in Table 1). As explained in Mamouri and Ansmann (2014), two methods are available for the identification and quantification of the dust contribution to total particle backscattering and extinction. The so-called onestep method is used to separate non-dust particle backscattering from backscattering by fine and coarse dust particles. We assume a particle linear depolarization ratio of 0.05 for non-dust particles and 0.31 for dust particles so that depolarization ratios $<0.05$ and $>0.31$ indicate pure non-dust and pure dust aerosol backscattering, respectively. Mixtures are indicated by depolarization ratios from $>0.05$ to $<0.31$ and are separated by means of Eq. (3) in Mamouri and Ansmann (2014). The two-step method distinguishes backscattering from non-dust aerosol, fine-mode dust, and coarsemode dust particles. Non-dust particles cause a particle linear depolarization ratio of 0.05 or less, fine-mode dust a depolarization ratio of 0.16 , and coarse-mode desert dust a particle depolarization ratio of 0.39 . In the first step, we separate the coarse-mode dust backscatter coefficient and the residual particle backscatter coefficient (non-dust plus fine-dust particle backscattering) using Eq. (6) in Mamouri and Ansmann (2014), and in the second round we separate the non-dust backscatter coefficient from the fine-dust backscatter coefficient using Eq. (11) in Mamouri and Ansmann (2014). In the case of desert dust observation on 29 September 2011, however, both methods lead to almost the same profile for the total (fine plus coarse-mode) dust backscatter coefficient and the respective total dust extinction coefficient in the pronounced dust layer above $500 \mathrm{~m}$ height (above the polluted boundary layer). The one-step and two-step solutions for the dust extinction coefficient are shown in the right panel of Fig. 1. On 27 September 2011, we observed a smoke-dust plume over Limassol with dominating fine-mode smoke as well as fine-mode soil dust (Mamouri and Ansmann, 2014; Nisantzi et al., 2014). A pronounced coarse mode was missing. Under these conditions, only the two-step method delivers correct results. The one-step and two-step retrieval profiles do not match in this case. More details are given by Mamouri and Ansmann (2014). To avoid such complicated situations in this first paper on lidar-derived INC retrievals, we concentrate on desert dust plumes only, and use the wellestablished one-step method in the case studies presented in Sect. 4. The source region of the observed dust can easily be identified by means of backward trajectory analysis.

The dust extinction coefficient $\sigma_{\mathrm{d}}$ at $532 \mathrm{~nm}$ (step 3 in Table 1) shown in Fig. 1 is obtained from the dust backscatter coefficient $\beta_{\mathrm{d}}$ by multiplying $\beta_{\mathrm{d}}$ with the dust lidar ratio which was obtained before as the optimum dust lidar ratio from the particle backscatter retrieval after Mamouri et al. (2013). The dust lidar ratio is $43 \mathrm{sr}$ for the 27 September soil-dust case, and $39 \mathrm{sr}$ for the desert dust observation on 


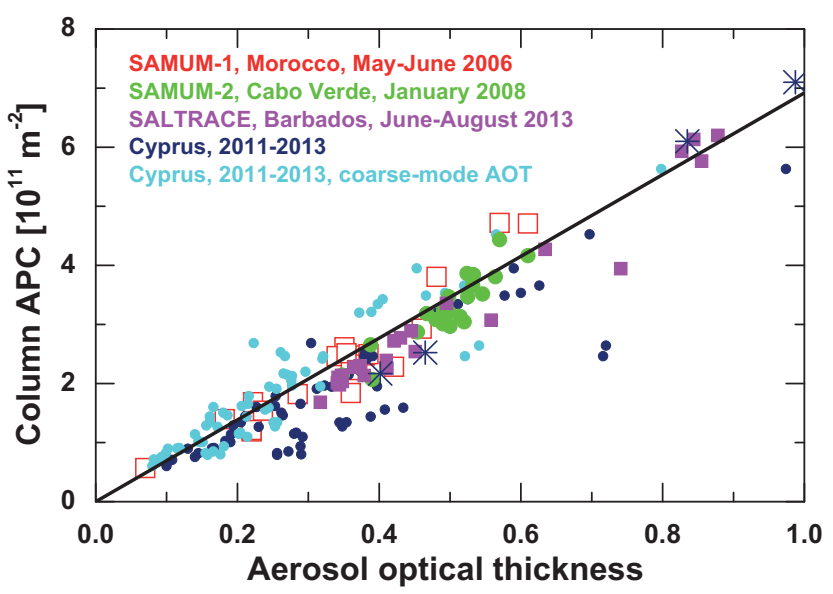

Figure 2. Correlation between aerosol optical thickness $(500 \mathrm{~nm}$ AOT) and column-integrated aerosol particle number concentration (column $\mathrm{APC}_{280}$ ) considering particles with $r>280 \mathrm{~nm}$. Desert-dust-dominated observations from several field campaigns (SAMUM-1, large red open squares, SAMUM-2, green circles, SALTRACE, small pink squares) and from long-term observations at Limassol from 2011 to 2013 are considered. For Cyprus, coarsemode (light blue circles) and total (fine + coarse-mode, deep blue circles) AOTs are correlated with column $\mathrm{APC}_{280}$. In the case of the stars (four Cyprus observations with total AOT from 1.6-4), AOT and column APC values are divided by 4 . Least squares fitting to all shown data (except the dark blue Cyprus values) yield the black solid line with the slope of $6.85 \times 10^{11} \mathrm{~m}^{-2}$.

29 September 2011. Both dust lidar ratios are characteristic of the Middle East region (Schuster et al., 2012; Mamouri et al., 2013). The uncertainty in the desert dust extinction coefficients is on the order of $20 \%$ (Tesche et al., 2009a; Mamouri and Ansmann, 2014) with a range from $10 \%$ for strong dust outbreaks and $30 \%$ for moderate to background dust conditions.

\subsection{Part 2: From dust extinction to $\mathrm{APC}_{280}$}

In the next step (step 4 in Table 1), we estimate the number concentration of large particles, $\mathrm{APC}_{280}$ (denoted as $n_{\mathrm{d}, 280}$ in Eq. (1)) from the $532 \mathrm{~nm}$ dust extinction coefficient $\sigma_{\mathrm{d}}$ in $\mathrm{Mm}^{-1}$ by means of

$n_{\mathrm{d}, 280}(z)=c_{\mathrm{d}, 280} \cdot \sigma_{\mathrm{d}}(z)$

with the conversion factor $c_{\mathrm{d}, 280}=0.673\left(\right.$ in $\mathrm{Mmcm}^{-3}$ ). This conversion factor is obtained from a comprehensive analysis of AERONET sun/sky photometer observations during strong Saharan dust outbreaks reaching Ouarzazate, Morocco, Praia, Cabo Verde, Barbados, and Limassol, Cyprus. An overview of the AERONET measurements considered in our study is shown in Fig. 2. The column-integrated value of the particle number concentration $\mathrm{APC}_{280}$ is plotted against $\mathrm{AOT}$ at $500 \mathrm{~nm}$ (column-integrated extinction coefficient). In the following we assume equal dust extinction at the laser
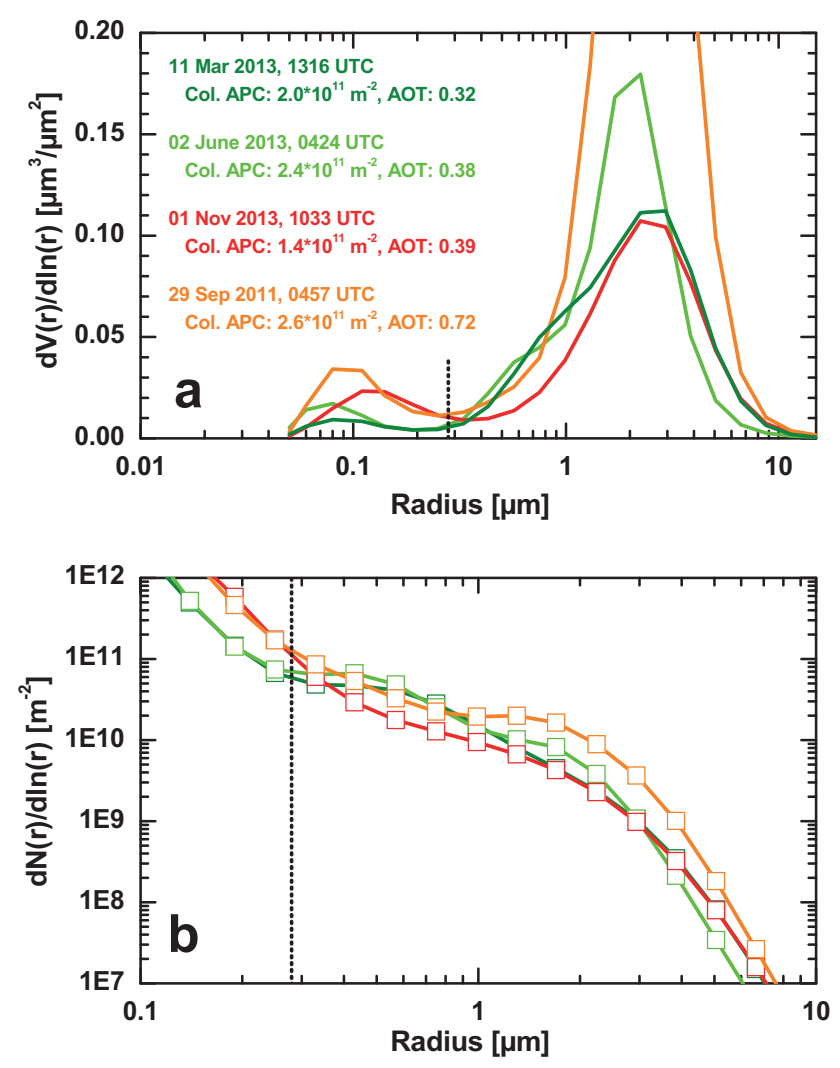

Figure 3. Column-integrated particle volume size distribution (a) and respective particle number size distribution (b) derived from AERONET sun/sky photometer observations at Limassol, Cyprus. Two Saharan dust cases (11 March 2013, olive, 2 June 2013, green) and two Middle East desert dust cases (29 September 2011, orange, 1 November 2013, red) are shown. The dotted vertical lines at $0.28 \mu \mathrm{m}$ indicate the lower limit of the particle radius range considered in the calculation of column $\mathrm{APC}_{280}$, which is defined as the sum of all particles larger than $280 \mathrm{~nm}$ in radius. The column $\mathrm{APC}_{280}$ values for the four measurement cases are given as numbers together with $500 \mathrm{~nm}$ total AOT in panel (a).

wavelength of $532 \mathrm{~nm}$ and the AERONET photometer wavelength of $500 \mathrm{~nm}$, i.e., we ignore a weak wavelength dependence of dust backscattering and extinction in the 500$550 \mathrm{~nm}$ wavelength range.

The determination of the column $\mathrm{APC}_{280}$ values from the basic AERONET information (column particle volume size distribution) is illustrated in Fig. 3. Particle volume size distributions measured at Limassol during two dust outbreaks from the Middle East (1 November 2013 and 29 September 2011) and two outbreaks from the Sahara (11 March and 2 June 2013) are shown in Fig. 3a. The particle volume size distribution is retrieved for 22 logarithmically equidistant discrete radius points $r_{i}$ with index $i$ from 1 to 22 . The particle radius range from $r_{1}=0.05 \mu \mathrm{m}$ to $r_{22}=15 \mu \mathrm{m}$ is covered. Each radius $r_{i}$ represents a radius interval of logarithmically equal width of about 0.27 . To obtain the particle 


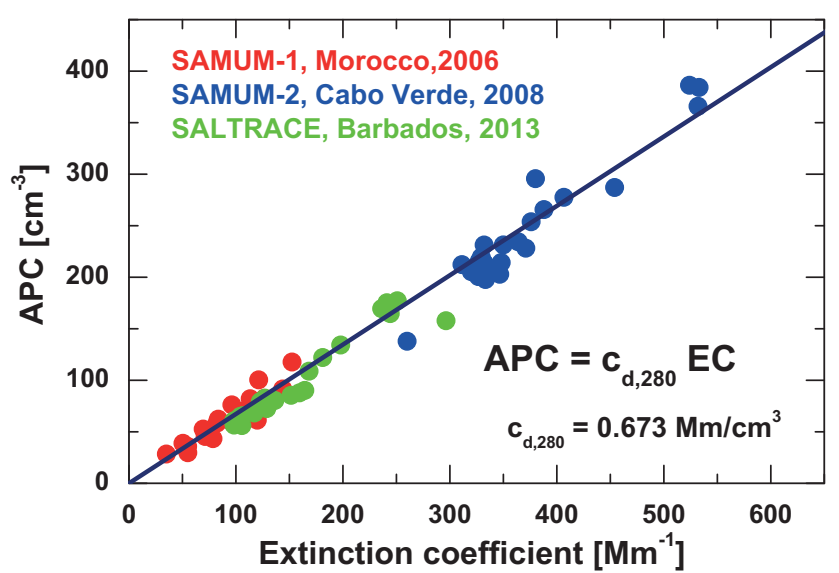

Figure 4. Relationship between dust layer mean $500 \mathrm{~nm}$ extinction coefficient (EC) and dust layer mean $\mathrm{APC}_{280}$ for observations taken during three desert dust field campaigns at Morocco, Cabo Verde, and Barbados. The linear regression yields $c_{\mathrm{d}, 280}=0.673 \pm 0.07 \mathrm{Mm} \mathrm{cm}^{-3}$. The correlation coefficient is $0.915 . c_{\mathrm{d}, 280}$ is used in Eq. (1).

number concentration for each individual radius class shown in Fig. 3b, we simply divided the volume concentration of a given radius interval (or for the discrete radius point $r_{i}$ ) by the volume of a single particle with radius $r_{i}$.

The column $\mathrm{APC}_{280}$ value is then simply given by the sum of all particles of the radius classes with radii $r_{i} \geq 330 \mathrm{~nm}$ and includes therefore all particles with roughly $r>280 \mathrm{~nm}$ (the part of the size spectrum on the right side of the dashed vertical line in Fig. 3b), when taking the width of the radius interval around $330 \mathrm{~nm}$ into account. The radius interval for $r_{8}=330 \mathrm{~nm}$ roughly represents the radius interval from 280 to $380 \mathrm{~nm}$. As mentioned before, we use $\mathrm{APC}_{280}$ instead of $\mathrm{APC}_{250}$ as originally suggested by DeMott et al. (2010) for the sake of simplicity. We simply add the particle number concentrations of the radius classes 8-22 and avoid analyzing the radius class $7(200-280 \mathrm{~nm}$ radius interval) for the contribution of $250-280 \mathrm{~nm}$ particles to the class-7 particle number concentration. $\mathrm{APC}_{250}$ is about $10-15 \%$ larger than $\mathrm{APC}_{280}$.

A good correlation between the $500 \mathrm{~nm}$ AOT and the column-integrated $\mathrm{APC}_{280}$ was found for all dust observations in Morocco, Cabo Verde, and Barbados (see Fig. 2). For dust outbreaks towards Limassol, Cyprus, the correlation was lower because of the contribution of omnipresent anthropogenic aerosol pollution to the total AOT in the eastern Mediterranean. The correlation between the coarse-mode AOT and column $\mathrm{APC}_{280}$ is much better. The coarse-mode AOT is largely determined by light extinction by dust particles. From all the AERONET data in Fig. 2 we conclude that a clear and close relationship exists between desert-dust $\mathrm{APC}_{280}$ and the dust-related extinction coefficient. According to the regression line in Fig. 2 the column $\mathrm{APC}_{280}$ is ap- proximately given by AOT $(500 \mathrm{~nm})$ multiplied by a factor of $6.85 \times 10^{11} \mathrm{~m}^{-2}$.

To translate the column-related findings in Fig. 2 into scales of particle extinction coefficient (measurable with lidar) and respective particle number concentration, we simply used the layer depth information from the lidar observations in Morocco, Cabo Verde, and Barbados. The dust layers were typically well mixed and reached from the surface to 5-6 km heights (Morocco, summer 2006), from the surface to 1.0$1.5 \mathrm{~km}$ heights (Cabo Verde, winter 2008), and from 1.0 to 4-6 km heights (Barbados, summer 2013). We divided the individual $\mathrm{AOT}$ and column $\mathrm{APC}_{280}$ pairs by the respective layer depths and obtained in this way the correlation shown in Fig. 4. We ignore here a small contribution of marine particles $(<20 \%$ contribution to the $500 \mathrm{~nm}$ AOT during the major dust outbreak situations) to the dust observations at Cabo Verde and Barbados. The linear regression yield a clear relationship between the dust extinction coefficient and $\mathrm{APC}_{280}$ (Eq. (1), step 4 in Table 1). The correlation coefficient is 0.91 . The slope of the regression line in Fig. 2 of 0.685 (in units of $10^{12} \mathrm{~m}^{-2}$ ) is slightly steeper than the respective one in Fig. 4 of 0.673 (in $\mathrm{Mm} \mathrm{cm}^{-3}$ ) because the regression in Fig. 2 includes the Cyprus data (coarse-mode AOT values).

The overall uncertainty in the lidar-derived $\mathrm{APC}_{280}$ values is estimated to be on the order of $30 \%$, keeping the $20 \%$ uncertainty in the determination of the dust particle extinction coefficient $\sigma_{\mathrm{d}}$ in mind and assuming a further uncertainty on the order of $20 \%$ in the conversion of $\sigma_{\mathrm{d}}$ into $\mathrm{APC}_{280}$ values. This $20 \%$ uncertainty includes a potential error of $10-15 \%$ of the AERONET-derived $\mathrm{APC}_{280}$ value obtained by applying an inversion algorithm to the basic spectral AOT and sky radiance observations. Studies of Toledano et al. (2011) and Müller et al. (2012), which compared AERONET size distributions with the respective airborne in situ observations during the SAMUM campaigns, show that the uncertainty in terms of $\mathrm{APC}_{280}$ obtained from the AERONET data is on the order of $<20 \%$. There may be situations with giant dust particles ( $>15 \mu \mathrm{m}$ in radius), for example during dust storms close to the Saharan source region. These giant dust particles are not considered in the AERONET retrieval of the volume size distribution. However, the impact of these missing giant particles on the AERONET results seems to be small, given the high overall correlation between $\mathrm{APC}_{280}$ and $\sigma_{\mathrm{d}}$ in Fig. 4 which includes SAMUM-1 results (Morocco, close to the dust source) as well as SALTRACE observations (Barbados, 5000-8000 km west of the main dust sources).

It should also be clearly mentioned in this context that there is no real alternative to AERONET observations shown in Figs. 2 and 4. Alternative measurements could be airborne in situ observations of aerosol microphysical and optical properties. But airborne observations are expensive and thus rare from the statistical point of view. Only AERONET can provide statistically dense, high-quality data sets of optical and microphysical properties of aerosol particles for the same air column at undisturbed ambient conditions. Ex- 
actly those data are needed for our correlation study. Wellestablished and approved methods are available to derive particle size distributions with high accuracy and uncertainties below 10-20\% (Dubovik and King, 2000; Dubovik et al., 2006). Complementary methods can be used in addition to check the quality of the microphysical products (O'Neill et al., 2003) and the consistency between the retrieved optical and microphysical properties.

\subsection{Part 3: Estimation of INC from $\mathrm{APC}_{280}$}

The retrieval of $\mathrm{APC}_{280}$ from $\sigma_{\mathrm{d}}$ is the basic lidar contribution to the estimation of the INC profiles. Part 3 now provides the link to the published INC parameterizations (step 5 in Table 1) gained from comprehensive INC laboratory and field studies.

The INC parameterizations introduced by DeMott et al. $(2010,2015)$ hold for standard (std) pressure $\left(p_{0}=\right.$ $1013 \mathrm{hPa})$ and temperature $\left(T_{0}=273.16 \mathrm{~K}\right)$ conditions so that we have to convert each profile value $\operatorname{APC}_{280}\left(p_{z}, T_{z}\right)$ from ambient pressure $p_{z}$ and temperature $T_{z}$ at height $z$ to $\mathrm{APC}_{280}\left(p_{0}, T_{0}\right)$ by using the factor $\left(T_{z} p_{0}\right) /\left(T_{0} p_{z}\right)$.

DeMott et al. (2010) introduced a so-called global (aerosol-type-independent) INC parameterization:

$$
\begin{aligned}
& n_{\mathrm{IN}}\left(p_{0}, T_{0}, T_{z}\right)=a\left(273.16-T_{z}\right)^{b} \\
& \times n_{\mathrm{a}, 280}\left(p_{0}, T_{0}\right)^{\left[c\left(273.16-T_{z}\right)+d\right]},
\end{aligned}
$$

with $n_{\mathrm{a}, 280}$ (in std cm ${ }^{-3}$ ) representing $\mathrm{APC}_{280}, n_{\mathrm{IN}}$ (in std $\mathrm{L}^{-1}$ ) representing INC, $a=0.0000594, b=3.33, c=$ $0.0265, d=0.0033$, and temperature $T(z)$ in Kelvin $(<$ $273.16 \mathrm{~K}$ ). As mentioned, we use $n_{\mathrm{d}, 280}$ instead of $n_{\mathrm{d}, 250}$ as given in the original formula of DeMott et al. (2010).

DeMott et al. (2015) recently introduced another INC parameterization scheme which is explicitly developed for mineral dust:

$$
\begin{aligned}
& n_{\mathrm{IN}}\left(p_{0}, T_{0}, T_{z}\right)=f_{\mathrm{d}} n_{\mathrm{a}, 280}\left(p_{0}, T_{0}\right)^{\left[a_{\mathrm{d}}\left(273.16-T_{z}\right)+b_{\mathrm{d}}\right]} \\
& \quad \times \exp \left[c_{\mathrm{d}}\left(273.16-T_{z}\right)+d_{\mathrm{d}}\right],
\end{aligned}
$$

with the so-called atmospheric correction factor $f_{\mathrm{d}}=3, a_{\mathrm{d}}=$ $0.074, b_{\mathrm{d}}=3.8, c_{\mathrm{d}}=0.414$, and $d_{\mathrm{d}}=-9.671$. Finally, we transfer the obtained INC values $n_{\mathrm{IN}}\left(p_{0}, T_{0}, T_{z}\right)$ to the ones for ambient pressure and temperature conditions, $n_{\mathrm{IN}}\left(p_{z}, T_{z}\right)$, by multiplying $n_{\mathrm{IN}}\left(p_{0}, T_{0}, T_{z}\right)$ with the factor $\left(T_{0} p_{z}\right) /\left(T_{z} p_{0}\right)$.

According to DeMott et al. (2010, 2015), Eqs. (2) and (3) can be used to estimate INC for immersion freezing processes and are applicable to the temperature range from -9 to $-35^{\circ} \mathrm{C}$ (Eq. 2) and -21 to $-35^{\circ} \mathrm{C}$ (Eq. 3). In Sect. 4 (results), we use these immersion-freezing-based parameterizations for higher as well as lower temperatures. According to Wex et al. (2014) ice nucleation for coated mineral dust particles (coated with natural and/or anthropogenic soluble material) can be described as immersion freezing as well.

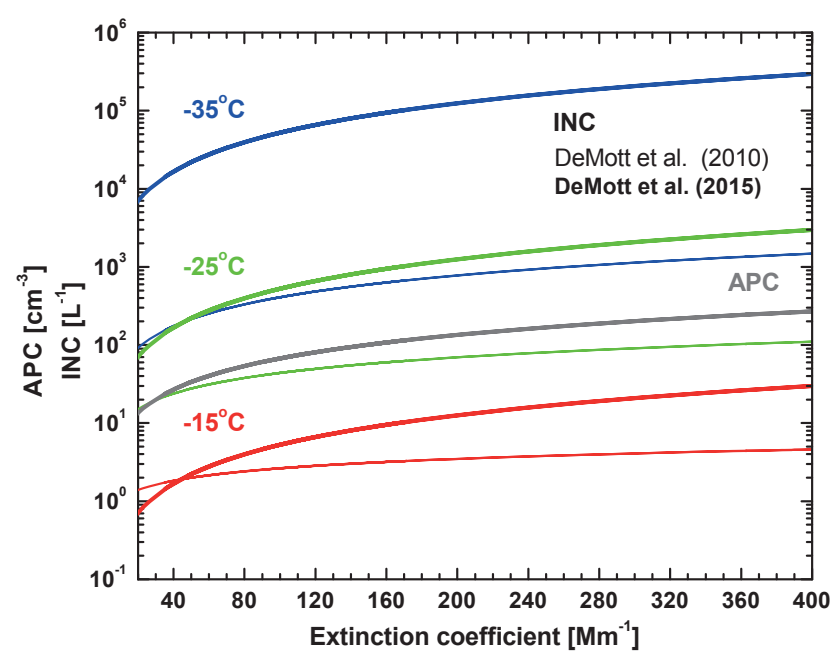

Figure 5. Relationship between dust extinction coefficient and $\mathrm{APC}_{280}$ (grey line) after Eq. (1) and INC after Eq. (2) (thin lines) (DeMott et al., 2010) and Eq. (3) (thick lines) (DeMott et al., 2015) for temperatures of $-15,-25$, and $-35^{\circ} \mathrm{C}$. The full range of dust extinction coefficients from 30 to $400 \mathrm{Mm}^{-1}$ measured on 29 September 2011 (Fig. 1) is shown.

Above the deliquescence relative humidity, additional water is added to the coating and a solution shell forms around the particles, causing them to nucleate ice from concentrated solutions via the immersion freezing pathway, taking a freezing point depression into account.

Regarding uncertainties in the INC computation, we estimate that Eq. (2) allows for a prediction of dust-related INC within an uncertainty range of a factor of 5-10 for temperatures from -5 to $-25^{\circ} \mathrm{C}$. The parameterization after Eq. (2) is based on observational data collected during nine field studies. These field studies were performed at a variety of locations around the globe over a 14 -year period. DeMott et al. (2010) further pointed out that an INC uncertainty of an order of magnitude is still acceptable for cloud process modeling. The uncertainties are lower and within a factor of 2 when using Eq. (3) (DeMott et al., 2015). From the comparison with the results obtained with Eq. (3) in Fig. 5 and in the next section, we can conclude that Eq. (2) underestimates the dust-related INC by up to a factor of 100 for temperatures below $-30^{\circ} \mathrm{C}$.

Regarding the overall uncertainty of our lidar-based INC retrieval we can summarize that the profile of $\mathrm{APC}_{280}$ can be derived from the dust extinction coefficients with a relative error of the order of $30 \%$ and that the estimation of INC profiles is therefore possible within an overall factor of 3 by applying Eq. (3).

Figure 5 provides an overview of the retrieval approach (steps 3-5 in Table 1) for the dust outbreak on 29 September 2011 shown in Fig. 1. Dust extinction values range from 30 to $400 \mathrm{Mm}^{-1}$. The grey $\mathrm{APC}_{280}$ curve in Fig. 5 describes the linear increase of the large particle number concentration 


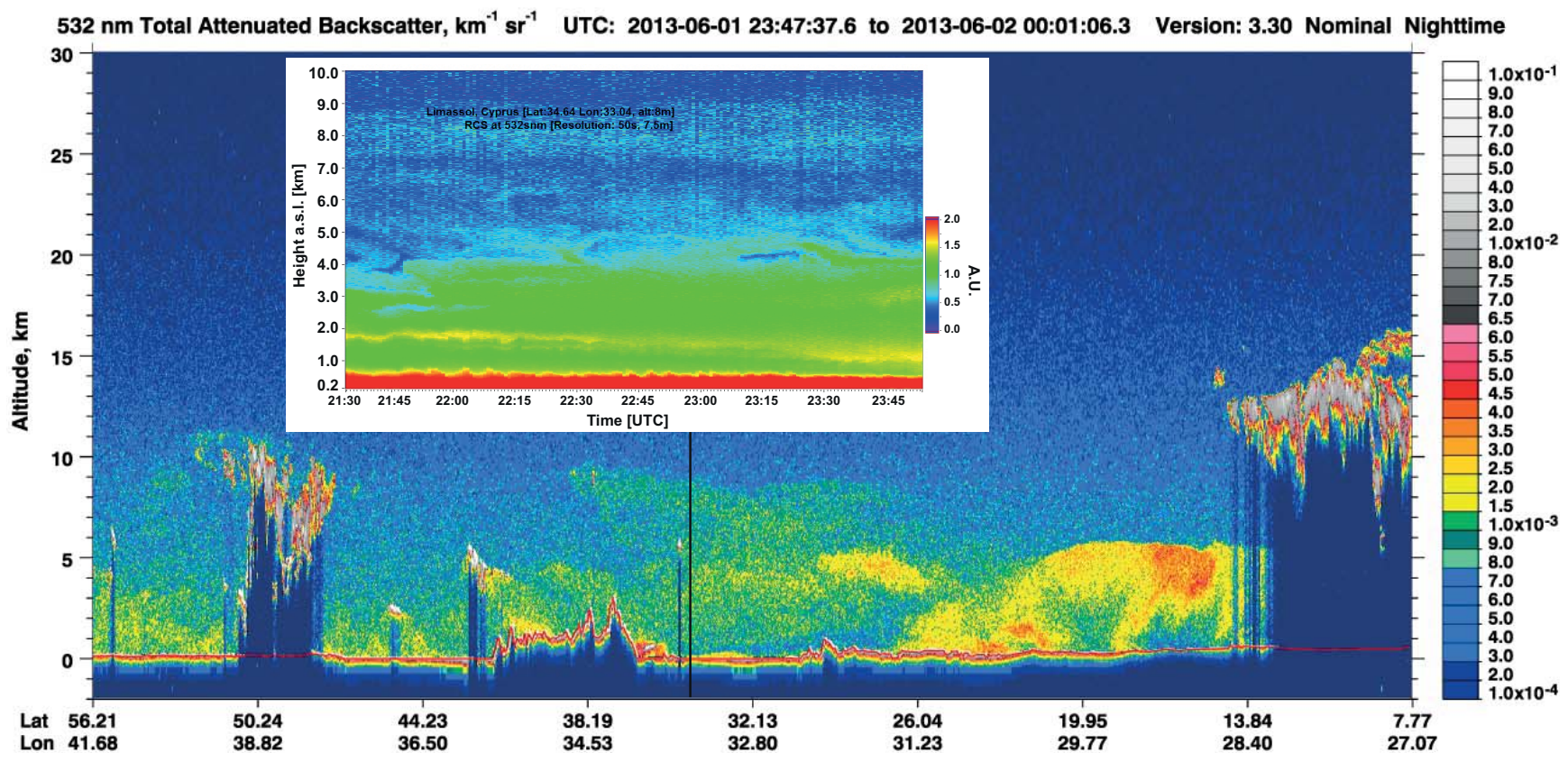

Figure 6. CALIOP measurement (height versus latitude/longitude display) of the attenuated $532 \mathrm{~nm}$ particle backscatter coefficient during an overpass $45 \mathrm{~km}$ to the east of Limassol from 1 June 2013, 23:47 UTC (universal time coordinated), to 2 June 2013, 00:01 UTC. Desert dust layers are given in green to yellow colors and reach up to $4-10 \mathrm{~km}$ height. The inserted height-time display shows the CUT lidar observation of the range-corrected cross-polarized $532 \mathrm{~nm}$ backscatter lidar signal on 1 June 2013, 21:30-23:55 UTC. Dust (green, yellow, and light blue layers) is observed up to $9-10 \mathrm{~km}$ height. The vertical black line indicates the closest position of CALIOP (laser footprint) to the ground-based CUT lidar at Limassol, Cyprus.

with increasing dust particle extinction coefficient $\sigma_{\mathrm{d}}$. To illustrate the large influence of the ambient temperature $T_{z}$ on INC, INC curves for $-15,-25$, and $-35^{\circ} \mathrm{C}$ are plotted in Fig. 5. As can be seen, a temperature decrease by $10^{\circ}$ causes an increase in the INC concentration by 2 orders of magnitude when using Eq. (3) and by a factor of 20 when using the more general aerosol parameterization (Eq. 2). Thus, a $10^{\circ}$ decrease in temperature (equivalent to about $1000-1500 \mathrm{~m}$ height change in the free troposphere) during lifting of air particles in a convective cloud tower leads to an enormous increase of the potential of a given dust load to initiate ice nucleation via immersion freezing.

\section{Results}

We applied our INC retrieval scheme to two CALIOP observations in the eastern Mediterranean close to Limassol, Cyprus. One of these overpasses took place during a strong Saharan dust outbreak on 1-2 June 2013. Traces of dust reached the cirrus level $(8-10 \mathrm{~km}$ height). During the second overpass, mineral dust was advected from the deserts in the Middle East on 1-2 November 2013. This second case can be regarded as representative for typical dust outbreaks with dust layers mainly in the lower free troposphere at heights between 1 and $5 \mathrm{~km}$ (Papayannis et al., 2008, 2009; Nisantzi et al., 2015).

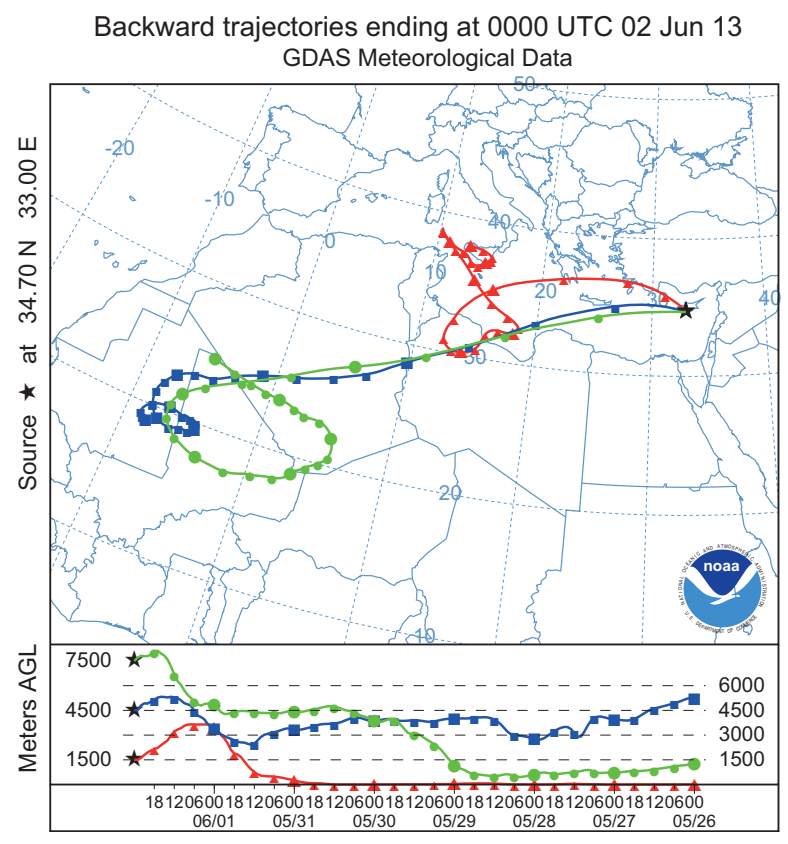

Figure 7. HYSPLIT 7-day backward trajectories arriving within the dust layer over Limassol, Cyprus, at 1500 (red), 4500 (blue), and $7500 \mathrm{~m}$ height (green) on 2 June 2013, 00:00 UTC. 


\subsection{CALIOP and CUT lidar observations during a Saharan dust outbreak in June 2013}

An overview of the dust and cloud observations of the spaceborne CALIOP lidar in the night of 1-2 June 2013 is shown in Fig. 6. The spaceborne lidar crossed eastern Ukraine $\left(52-56^{\circ} \mathrm{N}\right)$, the Black Sea area $\left(44-52^{\circ} \mathrm{N}\right)$, Turkey $(36-$ $\left.42^{\circ} \mathrm{N}\right)$, the eastern Mediterranean Sea $\left(30-36^{\circ} \mathrm{N}\right)$, Egypt $\left(22-32^{\circ} \mathrm{N}\right)$, and Sudan $\left(<22^{\circ} \mathrm{N}\right)$ within $12.5 \mathrm{~min}$ (corresponding to a distance of about $5000 \mathrm{~km}$ ). The backward trajectory analysis in Fig. 7 indicates the southern parts of the Sahara as sources for the dust observed in the middle and upper troposphere over the eastern Mediterranean.

Figure 8 compares the basic optical properties derived from the ground-based CUT lidar and the CALIOP observations. The nearest horizontal distance of the CALIOP laser footprint to Limassol was $45 \mathrm{~km}$. We used HYSPLIT forward and backward trajectory analysis to identify the air mass which was seen by both lidars. This air mass crossed Limassol about $1 \mathrm{~h}$ before reaching the CALIPSO flight track. Accordingly we selected the CUT lidar signal averaging period from 22:28 to 23:28 UTC. CALIPSO crossed the area at 23:53 UTC. The small deviations between the optical properties derived from the CALIOP and CUT lidar observations are mainly caused by different data analysis schemes, assumptions on input parameters, and the different signal averaging periods ( $1 \mathrm{~h}$ in the case of the CUT lidar, a few seconds in the case of CALIOP) (Mamouri et al., 2009). Different aerosol conditions in the lowest $500 \mathrm{~m}$ over the city of Limassol and over the open Mediterranean Sea (CALIOP) may widely explain the differences at heights below $500 \mathrm{~m}$.

The CALIOP products (backscatter and extinction coefficients) are determined by using lidar-ratio look-up tables (Omar et al., 2009; Kanitz et al., 2014). For desert dust scenarios, the lidar ratio is set to $40 \mathrm{sr}$. Our own measurements yield a particle (dust plus non-dust) lidar ratio of $55 \mathrm{sr}$ for the total tropospheric column following the complex data analysis procedure described by Mamouri et al. (2013). The lidar ratio of $55 \mathrm{sr}$ for this desert-dust-dominating scenario is in full agreement with respective SAMUM lidar-ratio observations (Tesche et al., 2009b).

For the INC retrieval, we smoothed the height profile of the particle backscatter coefficient measured with CALIOP with a vertical smoothing length of $600 \mathrm{~m}$. To reduce the noise in the CALIOP depolarization ratios, we also smoothed the basic cross-polarized and total particle backscatter coefficient profiles with $600 \mathrm{~m}$ vertical window length before we calculated the volume depolarization ratios and then the particle depolarization ratios. This procedure was recommended by Tesche et al. (2013). The left panel in Fig. 9 shows the smoothed basic CALIOP products (backscatter coefficient, depolarization ratio). The right panel presents the extinction profiles for desert dust particles and for remaining non-dust aerosol (marine and anthropogenic) particles calculated from the smoothed CALIOP profiles. The separation of the dust

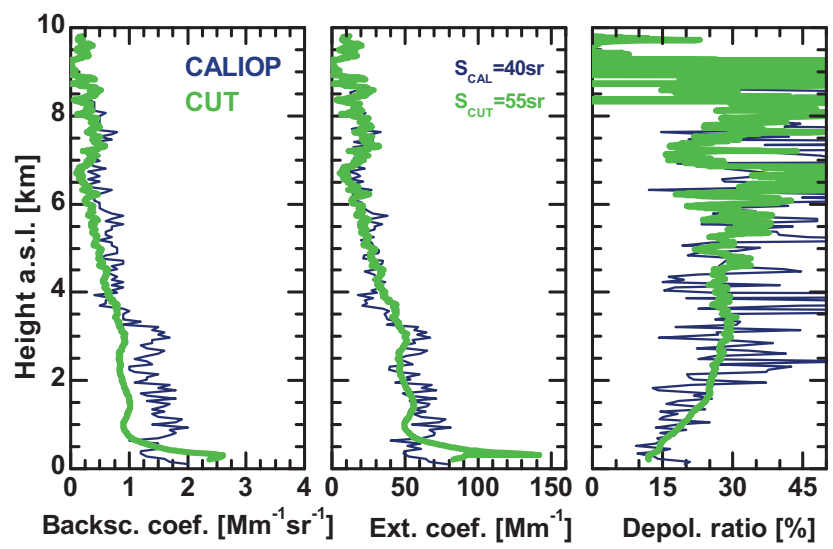

Figure 8. Comparison of profiles of particle backscatter coefficient, extinction coefficient, and particle linear depolarization ratio measured with ground-based CUT lidar at Limassol (thick green curves, 60 min means) on 1 June 22:28-23:28 UTC, and with spaceborne CALIOP (blue noisy curves, $45 \mathrm{~km}$ east of Limassol, during seconds 38-43 of 23:53 UTC). In the case of CALIOP, 135 signal profiles are averaged (nine level- 2 aerosol profiles, $45 \mathrm{~km}$ horizontal resolution). No vertical smoothing is applied to the CALIOP data. CUT lidar signal profiles were vertically smoothed by $180 \mathrm{~m}$. A lidar ratio of $S_{\mathrm{CAL}}=40 \mathrm{sr}$ was selected in the retrieval of CALIOP data and $S_{\mathrm{CUT}}=55 \mathrm{sr}$ (optimum lidar ratio for this Saharan dust case after Mamouri et al. (2013)) was applied in the CUT computation of backscatter and extinction profiles.

and non-dust optical properties was explained in Sect. 3.1. In the conversion of the backscatter coefficients to the respective dust and non-dust extinction coefficients we used lidar ratios of $50 \mathrm{sr}$ for non-dust particles and $55 \mathrm{sr}$ for Saharan dust particles.

Figure 10 presents the results for this CALIOP overpass case in terms of dust extinction coefficient $\sigma_{\mathrm{d}}, \mathrm{APC}_{280}$, and INC. The respective products derived from the ground-based CUT lidar observations are also shown. Because of the high temperatures over the eastern Mediterranean in the beginning of June 2013 , with surface temperatures close to $30^{\circ} \mathrm{C}$, INC values are only given for the upper part of the Saharan dust layer where temperatures $<0^{\circ} \mathrm{C}$ where given.

Significant differences are found for the different INC parameterizations. Compared to the INC profile using Eq. (2) (global aerosol INC parameterization), significantly higher INC values are obtained with Eq. (3) (mineral dust parameterization) for temperatures $<-20^{\circ} \mathrm{C}$. This reflects that desert dust particles are known to be very efficient ice nuclei at temperatures $<-20^{\circ} \mathrm{C}$, but not at temperatures $>-15^{\circ} \mathrm{C}$ (Ansmann et al., 2008; Murray et al., 2012). Consequently, for temperatures from -5 to $-15^{\circ} \mathrm{C}$ the INC estimates are slightly higher by using Eq. (2) compared to the INC values from Eq. (3). For higher temperatures $\left(0\right.$ to $\left.-5^{\circ} \mathrm{C}\right)$ the INC values are not trustworthy because these temperatures are far outside the temperature range for which the parameterizations (Eqs. 2, 3) were developed. Differences between 


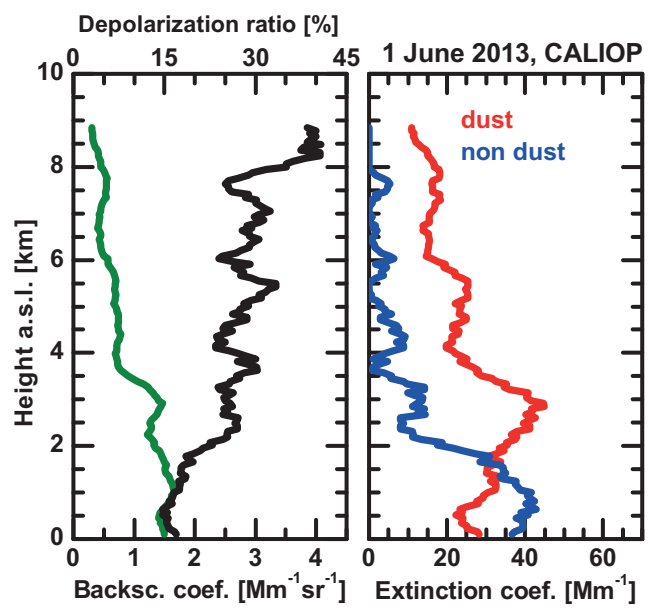

Figure 9. CALIOP data analysis products based on the 135 signal profile averages shown in Fig. 8: (Left) Vertical profiles of $532 \mathrm{~nm}$ particle backscatter coefficient (green) and particle linear depolarization ratio (black), and (right) derived particle extinction coefficients for non-dust (blue) and desert dust particles (red). The particle backscatter coefficients (left, green) are taken from the CALIOP data base and smoothed with $600 \mathrm{~m}$ gliding window length. The particle linear depolarization ratio is computed from the crosspolarized and total backscatter coefficient profiles after smoothing the profiles with $600 \mathrm{~m}$ vertical window length. Lidar ratios used in the backscatter-to-extinction conversion are $50 \mathrm{sr}$ for the non-dust particles and $55 \mathrm{sr}$ for Saharan dust.

the INC profiles derived from the CUT lidar and CALIOP observations are likewise small and mainly caused by differences in the temperature profiles over Limassol and above the CALIOP laser footprint.

This unique Saharan dust outbreak with dust traces up to $10 \mathrm{~km}$ provides a favorable opportunity to continue the discussion on the rather strong temperature influence on INC and the consequences for cloud glaciation. As can be seen, although the dust number concentration $\mathrm{APC}_{280}$ is almost constant with height in the layer from 6 to $8.5 \mathrm{~km}$ height, the INC values increase by a factor of 1000 , from $6\left(-12^{\circ} \mathrm{C}\right)$ to $8.5 \mathrm{~km}\left(-30^{\circ} \mathrm{C}\right)$ when the mineral dust INC parameterization (Eq. 3) is applied. This means that even traces of desert dust occurring at the base of an evolving convective cumulus tower can develop an enormous potential to glaciate the cloud system when lifted by updrafts over several kilometers.

\subsection{CALIOP overpass during a dust outbreak from the Middle East in November 2013}

A Middle East desert dust outbreak was observed on 12 November 2013. Figure 11 provides an overview of the CALIOP attenuated-backscatter observations. Figure 12 presents the respective HYSPLIT backward trajectories arriving at Limassol on 2 November 2013, 00:00 UTC, and shows the source regions of the dust (deserts in Saudi Arabia,

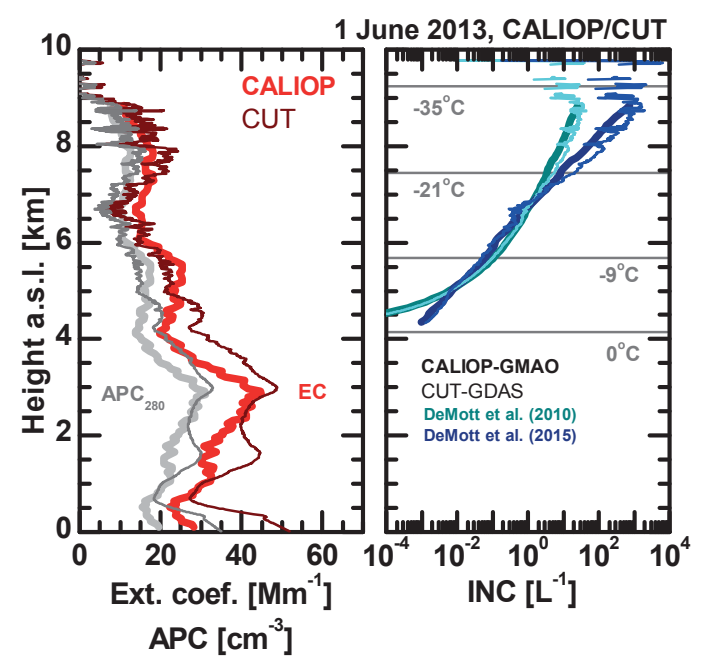

Figure 10. Profiles of $532 \mathrm{~nm}$ desert dust extinction coefficient $\sigma_{\mathrm{d}}$, $\mathrm{APC}_{280}$, and INC. GDAS profiles of temperature and pressure for the Limassol region were used in the CUT lidar data analysis (thin lines) and GMAO Data Assimilation System profiles of the meteorological parameters along the CALIOP flight track were used in the analysis of the space lidar observations (thick lines). INC profiles computed with Eq. (2) (DeMott et al., 2010) are shown as light blue lines (CALIOP, thick, CUT lidar, thin). INC profiles computed with Eq. (3) (DeMott et al., 2015) are shown as dark blue lines (CALIOP, thick, CUT lidar, thin). Grey horizontal lines indicate the temperature ranges for which the parameterizations are explicitly valid ( -9 to $-35^{\circ} \mathrm{C}$, Eq. (2), -21 to $-35^{\circ} \mathrm{C}$, Eq. (3)). Uncertainties are on the order of $20 \%$ (for $\sigma_{\mathrm{d}}$ ), $30 \%$ (for $\mathrm{APC}_{280}$ ), and within a factor of 3 (in the case of INC) when using the dust INC parameterization after DeMott et al. (2015).

Iraq, and Syria). In contrast to the foregoing case study, dust was detected at heights below $4 \mathrm{~km}$ only.

The CALIOP and CUT data analysis was performed in the same way as described in Sect. 4.1. The noisy CALIOP data profiles, averaged over a $45 \mathrm{~km}$ horizontal length, had to be smoothed with a $600 \mathrm{~m}$ vertical window length. We generally used particle lidar ratios around $40 \mathrm{sr}$ (for CALIOP as well as for the CUT lidar observations) in this case of a major Middle East desert dust outbreak. These low lidar ratios around $40 \mathrm{sr}$ are representative for Middle East desert dust (Schuster et al., 2012; Mamouri et al., 2013).

Figure 13 compares the CUT and CALIOP lidar findings for this dust outbreak in terms of dust extinction coefficient $\sigma_{\mathrm{d}}, \mathrm{APC}_{280}$, and INC. Because the CALIOP laser footprint was $180 \mathrm{~km}$ east of Limassol and both (CALIOP and CUT) observations were performed within a relatively small time window of less than $2 \mathrm{~h}$ (23:45 UTC on 1 November to 01:00 UTC on 2 November), different air masses were definitely observed (Pappalardo et al., 2010). This explains the differences between the two observations in terms of $\sigma_{\mathrm{d}}$ and $\mathrm{APC}_{280}$. Regarding INC, temperatures along the CALIPSO flight track were up to $2.5^{\circ} \mathrm{C}$ lower in the free 


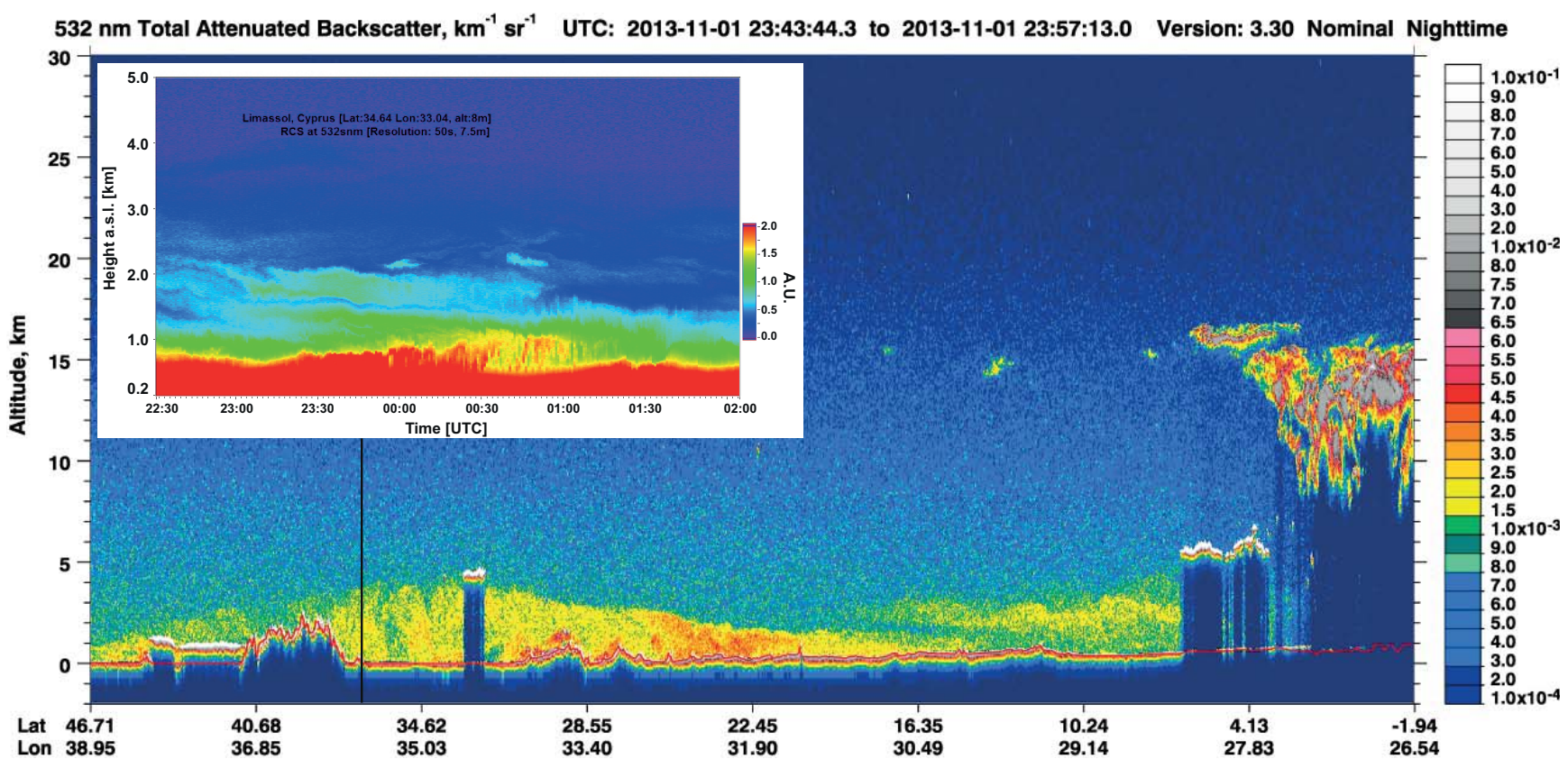

Figure 11. CALIOP measurement (height versus latitude/longitude display) of the attenuated $532 \mathrm{~nm}$ particle backscatter coefficient during an overpass $180 \mathrm{~km}$ to the east of Limassol on 1 November 2013, 23:43-23:57 UTC. Desert dust layers are given in green to yellow colors and reach up to about $4 \mathrm{~km}$ height. The inserted height-time display shows the CUT lidar observation of the cross-polarized range-corrected $532 \mathrm{~nm}$ backscatter signal from 1 November 2013, 22:30, to 2 November 2013, 02:00 UTC. The vertical black line indicates the closest position of CALIOP (laser footprint) to the ground-based CUT lidar at Limassol, Cyprus.

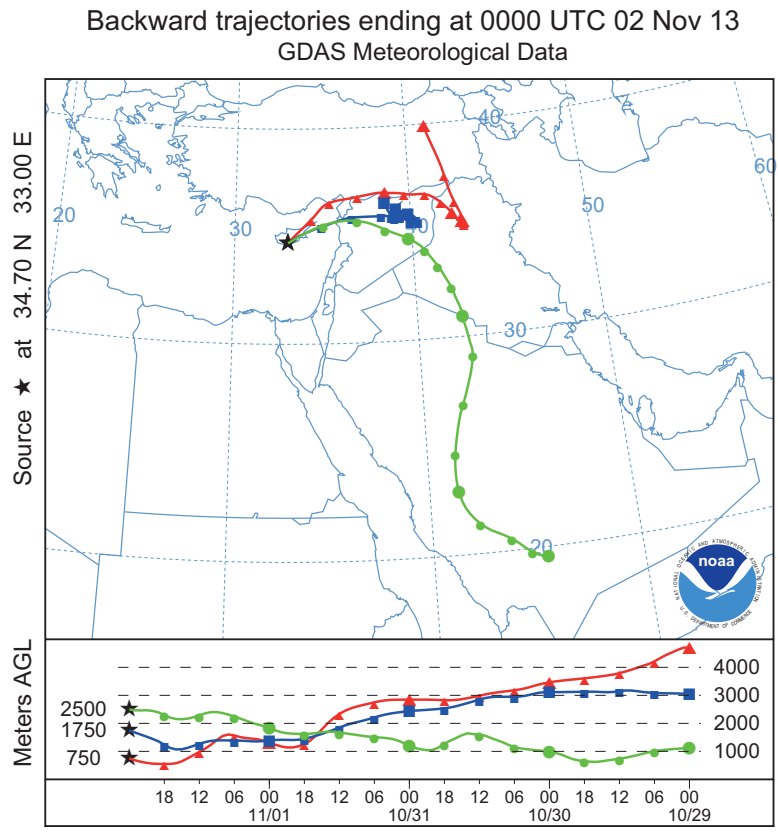

Figure 12. HYSPLIT 4-day backward trajectories arriving within the dust layer over Limassol, Cyprus, at 750 (red), 1750 (blue), and $2500 \mathrm{~m}$ height (green) on 2 November 2013, 00:00 UTC. troposphere above $600 \mathrm{~m}$ height compared to Limassol temperatures so that the CALIOP-derived INC values were considerably higher because of the lower temperatures and the, on average, higher $\mathrm{APC}_{280}$ values. However, the $0^{\circ} \mathrm{C}$ level was above $3 \mathrm{~km}$ and the $-5^{\circ} \mathrm{C}$ level was reached at $4 \mathrm{~km}$ height so that only a few INC estimates for the uppermost part of the dust layer could be calculated. Such conditions were already observed during the SAMUM-1 campaign in southern Morocco (Ansmann et al., 2008). Ice formation in altocumulus layers developing at the top of such dust layers was found to be almost impossible because of the high temperatures throughout the dust layers: only when cumulus convection was strong enough so that cloud parcels could penetrate deeply into the free troposphere could ice formation be observed.

Figure 13 contains further INC profiles. We shifted the GDAS and GMAO temperature profiles by $22-23^{\circ} \mathrm{C}$ so that the surface temperature was $0^{\circ} \mathrm{C}$ at both sites. We simulated these profiles to visualize the consequences (in terms of INC increase) of a horizontal transport of air masses towards colder areas, i.e., when such a warm dust plume is, e.g., advected to the north (towards Turkey, Black Sea, Russia, and Scandinavia) and gets colder by radiative cooling and mixing with colder air during the long-range transport. As can be seen, the potential of a given dust layer to initiate ice formation in water clouds steadily and strongly increases. As discussed already, the ice nucleation efficiency increases 


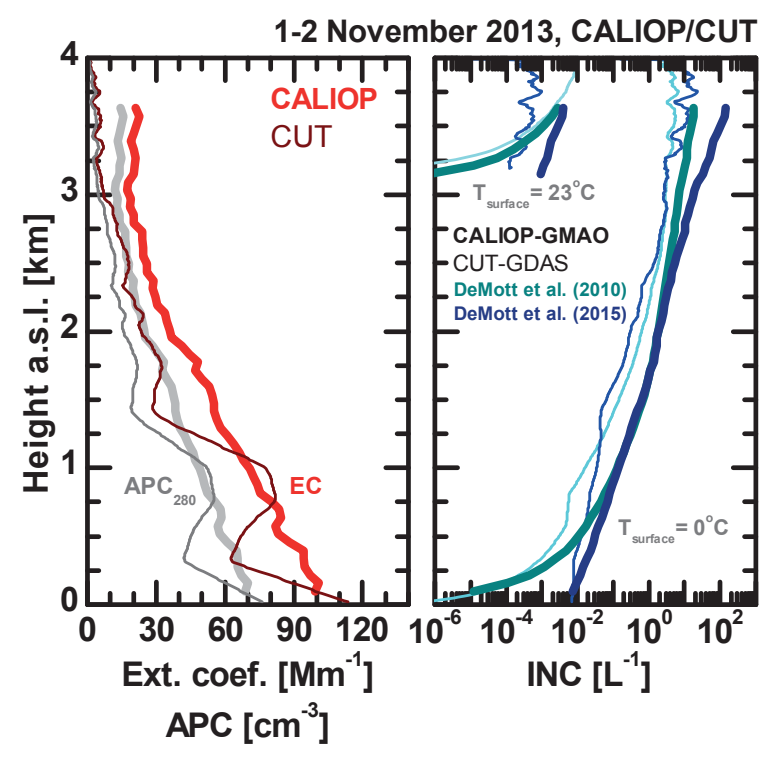

Figure 13. Same as Fig. 10, except for a Middle East desert dust outbreak on 1-2 November 2013. In the case of CALIOP profiles (180 km east of Limassol), again, 135 signal profiles ( $45 \mathrm{~km}$ horizontal resolution) are averaged, collected during seconds 8-14 of 23:47 UTC on 1 November 2013. The CUT lidar profiles show average values for the time period from 00:00 to 00:59 UTC on 2 November 2013. The original GDAS and GMAO temperature and pressure profiles were used in the computation of the INC profiles indicated by $T_{\text {surface }}=23{ }^{\circ} \mathrm{C}$. The GDAS and GMAO temperature profiles were shifted by $22 \mathrm{~K}$ (Limassol) and $23 \mathrm{~K}$ (CALIOP) in the case of the INC curves indicated by $T_{\text {surface }}=0^{\circ} \mathrm{C}$. Uncertainties are on the order of $20 \%$ (for $\sigma_{\mathrm{d}}$ ), $30 \%$ (for $\mathrm{APC}_{280}$ ), and within a factor of 3 (for INC) when using the dust INC parameterization after DeMott et al. (2015).

by 3-4 orders of magnitude if a dusty air mass is cooled by about $20^{\circ} \mathrm{C}$. These INC levels are further increased by the fact that air masses are usually also lifted by several kilometers during long-range transport over thousands of kilometers (Mattis et al., 2002; Ansmann et al., 2003).

\section{Conclusions}

A method has been introduced that permits the estimation of desert-dust-related INC profiles from polarization lidar measurements at $532 \mathrm{~nm}$ wavelength. Of key importance for a successful INC retrieval is a close relationship between the lidar-derived dust extinction coefficient $\sigma_{\mathrm{d}}$ and the number concentration $\mathrm{APC}_{280}$ of large particles with $r>280 \mathrm{~nm}$. Based on unique desert dust field observations and long-term studies with AERONET photometers we demonstrated that this close link is given for desert dust. The uncertainties for the different lidar products are on the order of $20 \%$ for the derived dust extinction coefficients, $30 \%$ for $\mathrm{APC}_{280}$, and within a factor of 3 for INC when using the recently developed dust INC parameterization of DeMott et al. (2015).
The approach paves the way for INC vertical profiling to support ground-based and airborne in situ IN characterization and to conduct a global, vertically resolved mapping of dust-related INC in the framework of spaceborne lidar missions such as CALIPSO (NASA) or EarthCARE (European SpaceAgency; Illingworth et al., 2015). This was demonstrated by two case studies of spaceborne CALIOP and ground-based CUT lidar measurements during overpasses of CALIOP over the eastern Mediterranean. Because there are already several dust-related global studies based on CALIOP observations (Liu et al., 2008; Tsamalis et al., 2013; Amiridis et al., 2013; Luo et al., 2015) with focus on geometrical and optical properties of desert dust, it should be a comparably easy effort to do the next step towards characterizing the aerosol conditions in terms of $\mathrm{APC}_{280}$ and INC. Such a global INC characterization may allow for an improved consideration of heterogeneous ice formation in atmospheric circulation models. However, we recommend establishing a global aerosol data set in terms of $\mathrm{APC}_{280}$ rather than of INC, and to combine the $\mathrm{APC}_{280}$ data set with actual temperature fields from numerical weather prediction models. This is a more flexible approach to account for the large influence of ambient temperature conditions on the efficiency of any given aerosol layer to initiate heterogeneous ice nucleation. Furthermore, the accuracy of desert-dust $\mathrm{APC}_{280}$ data sets is high, in comparison with the uncertainties in the INC estimates.

As an outlook, we need to study to what extent and with what uncertainty the method presented here can also be used for INC profiling during situations dominated by fine-mode aerosol such as urban haze, biomass burning smoke, or even fine-mode soil dust injected into the atmosphere during fire events (Nisantzi et al., 2014). Under such conditions, a good and clear correlation of the particle extinction coefficient and $\mathrm{APC}_{280}$ may no longer apply so that a good INC estimation is difficult. We may also test an alternative INC retrieval approach which relates INC to particle surface area rather than to APC (Niemand et al., 2012; Steinke et al., 2014; Hande et al., 2014).

Acknowledgements. The authors thank the CUT Remote Sensing Laboratory for their support. We thank Patric Seifert (TROPOS) for fruitful comments, and the SAMUM and SALTRACE lidar/photometer groups for taking care of all lidar and photometer observations. We are grateful to AERONET for high-quality sun/sky photometer measurements in Cyprus, Morocco, Cabo Verde, and Barbados. We thank Carlos Toledano for discussions on AERONET's size distribution retrieval. The authors gratefully acknowledge the NOAA Air Resources Laboratory (ARL) for the provision of the HYSPLIT transport and dispersion model and/or READY website (http://www.ready.noaa.gov) used in this publication. We thank the NASA Langley Research Center and the CALIPSO science team for the constant effort and improvement of the CALIPSO data. The research leading to these results has also received scientific support from the European Union Seventh 
Framework Programme (FP7/2011-2015) under grant agreement no. 262254 (ACTRIS project). We acknowledge funding from the EU FP7-ENV-2013 programme BACCHUS (impact of Biogenic vs. Anthropogenic emissions on Clouds and Climate: towards a Holistic UnderStanding), project no. 603445.

Edited by: G. Vaughan

\section{References}

Amiridis, V., Wandinger, U., Marinou, E., Giannakaki, E., Tsekeri, A., Basart, S., Kazadzis, S., Gkikas, A., Taylor, M., Baldasano, J., and Ansmann, A.: Optimizing CALIPSO Saharan dust retrievals, Atmos. Chem. Phys., 13, 12089-12106, doi:10.5194/acp-1312089-2013, 2013.

Ansmann, A., Bösenberg, J., Chaikovsky, A., Comerón, A., Eckhardt, S., Eixmann, R., Freudenthaler, V., Ginoux, P., Komguem, L., Linné, H., López Márquez, M. A., Matthias, V., Mattis, I., Mitev, V., Müller, D., Music, S., Nickovic, S., Pelon, J., Sauvage, L., Sobolewsky, P., Srivastava, M. K., Stohl, A., Torres, O., Vaughan, G., Wandinger, U., and Wiegner, M.: Long-range transport of Saharan dust to northern Europe: The 11-16 October 2001 outbreak observed with EARLINET, J. Geophys. Res., 108, 4783, doi:10.1029/2003JD003757, 2003.

Ansmann, A., Mattis, I., Müller, D., Wandinger, U., Radlach, M., Althausen, D., and Damoah, R.: Ice formation in Saharan dust over central Europe observed with temperature/humidity/aerosol Raman lidar, J. Geophys. Res., 110, D18S12, doi:10.1029/2004JD005000, 2005

Ansmann, A., Tesche, M., Althausen, D., Müller, D., Freudenthaler, V., Heese, B., Wiegner, M., Pisani, G., Knippertz, P., and Dubovik, O.: Influence of Saharan dust on cloud glaciation in southern Morocco during SAMUM, J. Geophys. Res., 113, D04210, doi:10.1029/2007JD008785, 2008.

Ansmann, A., Tesche, M., Seifert, P., Althausen, D., Engelmann, R., Fruntke, J., Wandinger, U., Mattis, I., and Müller, D.: Evolution of the ice phase in tropical altocumulus: SAMUM lidar observations over Cape Verde, J. Geophys. Res., 114, D17208, doi:10.1029/2008JD011659, 2009.

Ansmann, A., Petzold, A., Kandler, K., Tegen, I., Wendisch, M., Müller, D., Weinzierl, B., Müller, T., and Heintzenberg, J.: Saharan mineral dust experiments SAMUM-1 and SAMUM-2: What have we learned?, Tellus B, 63, 403-429, doi:10.1111/j.16000889.2011.00555.x, 2011.

Ansmann, A., Althausen, D., Kanitz, T., Engelmann, R. Skupin, A., Baars, H., Klepel, A., Haarig, M., Heinold, B., Tegen, I., Toledano, C., Prescod, D., and Farrell, D., Saharan dust longrange transport: SALTRACE lidar observations at Barbados and aboard RV Meteor (Guadeloupe to Cape Verde) versus dust transport modelling, Proceedings, DUST 2014 - International Conference on Atmospheric Dust, Castellaneta Marina, Italy, 16 June 2014, 2014.

de Boer, G., Morrison, H., Shupe, M. D., and Hildner, R.: Evidence of liquid dependent ice nucleation in high-latitude stratiform clouds from surface remote sensors, Geophys. Res. Lett., 38, L01803, doi:10.1029/2010GL046016, 2011.
Bühl, J., Ansmann, A., Seifert, P., Baars, H., and Engelmann, R., Toward a quantitative characterization of heterogeneous ice formation with lidar/radar: comparison of CALIPSO/CloudSat with ground-based observations, Geophys. Res. Lett., 40, 4404-4408, doi:10.1002/grl.50792, 2013.

Cziczo, D. J., Froyd, K. D., Hoose, C., Jensen, E. J., Diao, M., Zondlo, M. A., Smith, J. B., Twohy, C. H., and Murphy, D. M.: Clarifying the dominant sources and mechanisms of cirrus cloud formation, Science, 340, 1320-1324, doi:10.1126/science.1234145, 2013.

DeMott, P. J., Prenni, A. J., Richardson, M. S., Kreidenweis, S. M., Twohy, C. H., and Rogers, D. C.: Ice nuclei variability, relation to ambient aerosol properties, and impacts on mixed-phase clouds, in Sixteenth ARM Science Team Meeting Proc., Albuquerque, NM, 27-31 March 2006.

DeMott, P. J., Prenni, A. J., Liu, X., Kreidenweis, S. M., Petters, M. D., Twohy, C. H., Richardson, M. S., Eidhammer, T., and Rogers, D. C.: Predicting global atmospheric ice nuclei distributions and their impacts on climate, P. Natl. Acad. Sci. USA, 107, 11217 11222, doi:10.1073/pnas.0910818107, 2010.

DeMott, P. J., Prenni, A. J., McMeeking, G. R., Sullivan, R. C., Petters, M. D., Tobo, Y., Niemand, M., Möhler, O., Snider, J. R., Wang, Z., and Kreidenweis, S. M.: Integrating laboratory and field data to quantify the immersion freezing ice nucleation activity of mineral dust particles, Atmos. Chem. Phys., 15, 393-409, doi:10.5194/acp-15-393-2015, 2015.

Draxler, R. R. and Hess, G. D.: Description of the HYSPLIT4 modeling system, NOAA Tech. Memo. ERL ARL-224, NOAA Air Resources Laboratory, Silver Spring, MD, 1997.

Draxler, R. R. and Hess, G. D.: An overview of the HYSPLIT_4 modeling system of trajectories, dispersion, and deposition. Aust. Meteor. Mag., 47, 295-308, 1998.

Draxler, R. R.: HYSPLIT4 user's guide, NOAA Tech. Memo. ERL ARL-230, NOAA Air Resources Laboratory, Silver Spring, MD, 1999.

Dubovik, O. and King, M.: A flexible inversion algorithm for retrieval of aerosol optical properties from Sun and sky radiance measurements, J. Geophys. Res., 105, 20673-20696, doi:10.1029/2000JD900282, 2000.

Dubovik, O., Sinyuk, A., Lapyonok, T., Holben, B. N., Mishchenko, M., Yang, P., Eck, T. F., Voltne, H., Munoz, O., Veihelmann, B., Van der Zande, W., J., Leon, J.-F., Sorokin, M., and Slutsker, I.,: Application of spheroid models to account for aerosol particle nonsphericity in remote sensing of desert dust, J. Geophys. Res., 111, D11208, doi:10.1029/2005JD006619, 2006.

Haarig, M., Althausen, D., Ansmann, A., Klepel, A., Baars, H., Kanitz, T., Prescod, D., and Farrell, D.: Long-range transport of Saharan dust measured with three-wavelength polarization lidar at Barbados, Proceedings, DUST 2014 - International Conference on Atmospheric Dust, Castellaneta Marina, Italy, 1-6 June 2014, 2014.

Hande, L. B., Engler, C., Hoose, C., and Tegen, I.: Seasonal variability of Saharan desert dust and ice nucleating particles over Europe, Atmos. Chem. Phys. Discuss., 14, 32071-32092, doi:10.5194/acpd-14-32071-2014, 2014.

Heintzenberg, J.: The SAMUM-1 experiment over Southern Morocco: overview and introduction, Tellus B, 61, 2-11, doi:10.1111/j.1600-0889.2008.00403.x, 2009. 
Holben, B. N., Eck, T. F., Slutsker, I., Tanré, D., Buis, J. P., Setzer, A., Vermote, E., Reagan, J. A., Kaufman, Y. J., Nakajima, T., Lavenu, F., Jankowiak, I., and Smirnov, A.: AERONET - a federated instrument network and data archive for aerosol characterization, Remote Sens. Environ., 66, 1-16, 1998.

Illingworth A.J.,, Hogan, R. J., O'Connor, E. J., Bouniol, D., Delanoe, J, Pelon, J., Protat, A., Brooks, M. E., Gaussiat, N., Wilson, D. R., Donovan, D. P., Klein Baltink, H., van Zadelhoff, G.-J., Eastment, J. D., Goddard, J. W. F., Wrench, C. L., Haeffelin, M., Krasnov, O. A., Russchenberg, H. W. J., Piriou, J.-M., Vinit, F., Seifert, A., Tompkins, A. M., and Willen, J., CLOUDNET: continuos evaluation of cloud profiles in seven operational models using ground-based observations, Bull. Amer. Meteorol. Soc., 88, 883-898, 2007.

Illingworth, A. J., Barker, H. W., Beljaars, A., Ceccaldi, M., Chepfer, H., Cole, J., Delanoe, J., Domenech, C., Donovan, D. P., Fukuda, S., Hirakata, M., Hogan, R. J., Huenerbein, H., Kollias, P., Kubota, T., Nakajima, T., Nakajima, T. Y., Nishizawa, T., Ohno, Y., Okamoto, H., Oki, R., Sato, K., Satoh, M., Shephard, M., Wandinger, U., Wehr, T., and Zadelhoff, G.-J.: THE EARTHCARE SATELLITE: The next step forward in global measurements of clouds, aerosols, precipitation and radiation, Bull. Amer. Meteorol. Soc., 96, doi:10.1175/BAMS-D-12-00227.1, in press, 2015.

Kamphus, M., Ettner-Mahl, M., Klimach, T., Drewnick, F., Keller, L., Cziczo, D. J., Mertes, S., Borrmann, S., and Curtius, J.: Chemical composition of ambient aerosol, ice residues and cloud droplet residues in mixed-phase clouds: single particle analysis during the Cloud and Aerosol Characterization Experiment (CLACE 6), Atmos. Chem. Phys., 10, 8077-8095, doi:10.5194/acp-10-8077-2010, 2010.

Kanitz, T., Seifert, P., Ansmann, A., Engelmann, R., Althausen, Casiccia, C., and Rohwer, E. G.: Contrasting the impact of aerosols at northern and southern midlatitudes on heterogeneous ice formation, Geophys. Res. Lett., 38, L17802, doi:10.1029/2011GL048532, 2011.

Kanitz, T., Ansmann, A., Foth, A., Seifert, P., Wandinger, U., Engelmann, R., Baars, H., Althausen, D., Casiccia, C., and Zamorano, F.: Surface matters: limitations of CALIPSO V3 aerosol typing in coastal regions, Atmos. Meas. Tech., 7, 2061-2072, doi:10.5194/amt-7-2061-2014, 2014.

Liu, D., Wang, Z., Liu, Z., Winker, D., and Trepte, C.: A height resolved global view of dust aerosols from the first year CALIPSO lidar measurements, J. Geophys. Res., 113, D16214, doi:10.1029/2007JD009776, 2008.

Luo, T., Wang, Z., Zhang, D., Liu, X., Wang, Y., and Yuan, R.: Global dust distribution from improved thin dust layer detection using A-train satellite lidar observations, Geophys. Res. Lett., 42, doi:10.1002/2014GL062111, 2015.

Mamouri, R. E. and Ansmann, A.: Fine and coarse dust separation with polarization lidar, Atmos. Meas. Tech., 7, 3717-3735, doi:10.5194/amt-7-3717-2014, 2014.

Mamouri, R. E., Amiridis, V., Papayannis, A., Giannakaki, E., Tsaknakis, G., and Balis, D. S.: Validation of CALIPSO spaceborne-derived attenuated backscatter coefficient profiles using a ground-based lidar in Athens, Greece, Atmos. Meas. Tech., 2, 513-522, doi:10.5194/amt-2-513-2009, 2009.

Mamouri, R. E., Ansmann, A., Nisantzi, A., Kokkalis, P., Schwarz, A., and Hadjimitsis, D.: Low Arabian dust extinction- to-backscatter ratio, Geophys. Res. Lett., 40, 4762-4766, doi:10.1002/grl.50898, 2013.

Mattis, I., Ansmann, A., Müller, D., Wandinger, U., and Althausen, D.: Dual-wavelength Raman lidar observations of the extinctionto-backscatter ratio of Saharan dust, Geophys. Res. Lett., 29, 1306, doi:10.1029/2002GL014721, 2002.

Murray, B. J., O'Sullivan, D., Atkinson, J. D., and Webb, M. E.: Ice nucleation by particles immersed in supercooled cloud droplets, Chem. Soc. Rev., 41, 6519-6554, doi:10.1039/c2cs35200a, 2012.

Martucci, G. and O'Dowd, C. D.: Ground-based retrieval of continental and marine warm cloud microphysics, Atmos. Meas. Tech., 4, 2749-2765, doi:10.5194/amt-4-2749-2011, 2011.

Müller, D., Lee, K.-H., Gasteiger, J., Tesche, M., Weinzierl, B., Kandler, K., Müller, T., Toledano, C., Otto, S., Althausen, D., and Ansmann, A.: Comparison of optical and microphysical properties of pure Saharan mineral dust observed with AERONET Sun photometer, Raman lidar, and in situ instruments during SAMUM 2006, J. Geophys. Res., 117, D07211, doi:10.1029/2011JD016825, 2012.

Niemand, M., Möhler, O., Vogel, B., Vogel, H., Hoose, C., Connolly, P., Klein, H., Bingemer, H., DeMott, P., Skrotzki, J., and Leisner, T.: Parameterization of immersion freezing on mineral dust particles: an application in a regional scale model, J. Atmos. Sci., 69, 3077-3092, 2012.

Nisantzi, A., Mamouri, R. E., Ansmann, A., and Hadjimitsis, D.: Injection of mineral dust into the free troposphere during fire events observed with polarization lidar at Limassol, Cyprus, Atmos. Chem. Phys., 14, 12155-12165, doi:10.5194/acp-1412155-2014, 2014.

Nisantzi, A., Mamouri, R. E., Ansmann, A., Schuster, G. L., and Hadjimitsis, D. G.: Middle East versus Saharan dust extinctionto-backscatter ratios, Atmos. Chem. Phys. Discuss., 15, 52035240, doi:10.5194/acpd-15-5203-2015, 2015.

Omar, A. H., Winker, D. M., Kittaka, C., Vaughan, M. A., Liu, Z., Hu, Y., Trepte, C. R., Rogers, R. R., Ferrare, R. A., Lee, K. P., Kuehn, R. E., and Hostetler, C. A.: The CALIPSO automated aerosol classification and lidar ratio selection algorithm, J. Atmos. Ocean. Technol., 26, 1994-2014, doi:10.1175/2009JTECHA1231.1, 2009.

O’Neill, N. T., Eck, T. F., Smirnov, A., Holben, B. N., and Thulasiraman, S.: Spectral discrimination of coarse and fine mode optical depth, J. Geophys. Res., 108, 4559, doi:10.1029/2002JD002975, 2003.

Papayannis, A., Amiridis, V., Mona, L., Tsaknakis, G., Balis, D., Bösenberg, J., Chaikovski, A., De Tomasi, F., Grigorov, I., Mattis, I., Mitev, V., Müller, D., Nickovic, S., Pérez, C., Pietruczuk, A., Pisani, G., Ravetta, F., Rizi, V., Sicard, M., Trickl, T., Wiegner, M., Gerding, M., Mamouri, R. E., D’Amico, G., and Pappalardo, G.: Systematic lidar observations of Saharan dust over Europe in the frame of EARLINET (2000-2002), J. Geophys. Res., 113, D10204, doi:10.1029/2007JD009028, 2008.

Papayannis, A., Mamouri, R. E., Amiridis, V., Kazadzis, S., Pérez, C., Tsaknakis, G., Kokkalis, P., and Baldasano, J. M.: Systematic lidar observations of Saharan dust layers over Athens, Greece in the frame of EARLINET project (2004-2006), Ann. Geophys., 27, 3611-3620, doi:10.5194/angeo-27-3611-2009, 2009.

Pappalardo, G., Wandinger, U., Mona, L., Hiebsch, A., Mattis, I., Amodeo, A., Ansmann, A., Seifert, P., Linné, H., Apiteley, 
A., Alados-Arboledas, L., Balis, D., Chaikovsky, A., D’Amico, G., De Tomasi, F., Freudenthaler, V., Giannakaki, E., Giunta, A., Grigorov, I., Iarlori, M., Madonna, F., Mamouri, R. E., Nasti, L., Papayannis, A., Pietruczuk, A., Pujamas, M., Rizi, V., Rocadenbosch, F., Russo, F., Schnell, F., Spinelli, N., Wang, X., and Wiegner, M.: EARLINET correlative measurements for CALIPSO: first intercomparison results, J. Geophys. Res., 115, D00H19, doi:10.1029/2009JD012147, 2010.

Pappalardo, G., Amodeo, A., Apituley, A., Comeron, A., Freudenthaler, V., Linné, H., Ansmann, A., Bösenberg, J., D’Amico, G., Mattis, I., Mona, L., Wandinger, U., Amiridis, V., AladosArboledas, L., Nicolae, D., and Wiegner, M.: EARLINET: towards an advanced sustainable European aerosol lidar network, Atmos. Meas. Tech., 7, 2389-2409, doi:10.5194/amt-7-23892014, 2014.

Richardson, M. S., DeMott, P. J., Kreidenweis, S. M., Cziczo, D. J., Dunlea, E. J., Jimenez, J. L., Thomson, D. S., Ashbaugh, L. L., Borys, R. D., Westphal, D. L., Casuccio, G. S., and Lersch, T. L.: Measurements of heterogeneous ice nuclei in the western United States in springtime and their relation to aerosol characteristics, J. Geophys. Res., 112, D02209, doi:10.1029/2006JD007500, 2007.

Schmidt, J., Ansmann, A. Bühl, J. Baars, H., Wandinger, U., Müller, D., and Malinka, A. V.: Dual-FOV Raman and Doppler lidar stduies of aerosol-cloud interactions: simultaneous profiling of aerosols, warm-cloud properties, and vertical wind, J. Geophys. Res., 119, L22222, 5512-5527, doi:10.1002/2013JD020424, 2014.

Schuster, G. L., Vaughan, M., MacDonnell, D., Su, W., Winker, D., Dubovik, O., Lapyonok, T., and Trepte, C.: Comparison of CALIPSO aerosol optical depth retrievals to AERONET measurements, and a climatology for the lidar ratio of dust, Atmos. Chem. Phys., 12, 7431-7452, doi:10.5194/acp-12-7431-2012, 2012.

Seifert, P., Ansmann, A., Mattis, I., Wandinger, U., Tesche, M., Engelmann, R., Müller, D., Pérez, C., and Haustein, K.: Saharan dust and heterogeneous ice formation: eleven years of cloud observations at a central European EARLINET site, J. Geophys. Res., 115, D20201, doi:10.1029/2009JD013222, 2010.

Seifert, P., Ansmann, A., Groß, S., Freudenthaler, V., Heinold, B., Hiebsch A., Mattis, I., Schmidt, J., Schnell, F., Tesche, M., Wandinger, U., and Wiegner, M.: Ice formation in ashinfluenced clouds after the eruption of the Eyjafjallajökull volcano in April 2010, J. Geophys. Res., 116, D00U04, doi:10.1029/2011JD015702, 2011.

Steinke, I., Hoose, C., Möhler, O., Connolly, P., and Leisner, T.: A new temperature and humidity dependent surface site density approach for deposition ice nucleation, Atmos. Chem. Phys. Discuss., 14, 18499-18539, doi:10.5194/acpd-14-18499-2014, 2014.
Tesche, M., Ansmann, A., Müller, D., Althausen, D., Engelmann, R., Freudenthaler, V., and Groß, S.: Vertically resolved separation of dust and smoke over Cape Verde using multiwavelength Raman and polarization lidars during Saharan Mineral Dust Experiment 2008, J. Geophys. Res., 114, D13202, doi:10.1029/2009JD011862, 2009a.

Tesche, M., Ansmann, A., Müller, D., Althausen, D., Mattis, I., Heese, B., Freudenthaler, V., Wiegner, M., Eseelborn, M., Pisani, G., and Knippertz, P.: Vertical profiling of Saharan dust with Raman lidars and airborne HSRL in southern Morocco during SAMUM, Tellus B, 61, 144-164, doi:10.1111/j.16000889.2008.00390.x, 2009b.

Tesche, M., Groß, S., Ansmann, A., Müller, D., Althausen, D., Freudenthaler, V., and Esselborn, M.: Profiling of Saharan dust and biomass-burning smoke with multiwavelength polarization Raman lidar at Cape Verde, Tellus B, 63, 649-676, doi:10.1111/j.1600-0889.2011.00548.x, 2011.

Tesche, M., Wandinger, U., Ansmann, A., Althausen, D., Müller, D., and Omar, A. H.: Ground-based validation of CALIPSO observations of dust and smoke in the Cape Verde region, J. Geophys. Res.-Atmos., 118, 2889-2902, doi:10.1002/jgrd.50248, 2013.

Toledano, C., Wiegner, M., Garhammer, M., Seefeldner, M., Gasteiger, J., Müller, D., and Koepke, P.: Spectral aerosol optical depth characterization of desert dust during SAMUM 2006, Tellus B, 61, 216-228, doi:10.1111/j.1600-0889.2008.00382.x, 2009.

Toldedano, C., Wiegner, M., Groß, S., Freudenthaler, V., Gasteiger, J., Müller, D., Müller, T., Schladitz, A., Weinzierl, B., Torres, B., and O'Neill, N. T.: Optical properties of aerosol mixtures derived from sun-sky radiometry during SAMUM-2, Tellus B, 63, 635648, doi:10.1111/j.1600-0889.2011.00573.x, 2011.

Tsamalis, C., Chédin, A., Pelon, J., and Capelle, V.: The seasonal vertical distribution of the Saharan Air Layer and its modulation by the wind, Atmos. Chem. Phys., 13, 11235-11257, doi:10.5194/acp-13-11235-2013, 2013.

Wandinger, U., Seifert, P., Wagner, J., Engelmann, R., Bühl, J., Schmidt, J., Heese, B., Baars, H., Hiebsch, A., Kanitz, T., Althausen, D., and Ansmann, A.: Integrated remote-sensing techniques to study aerosols, clouds, and their interaction Proceedings, 26th International Laser Radar Conference, Vol. I, 395-398, Porto Heli, Greece, 25-29 June 2012, 2012.

Wex, H., DeMott, P. J., Tobo, Y., Hartmann, S., Rösch, M., Clauss, T., Tomsche, L., Niedermeier, D., and Stratmann, F.: Kaolinite particles as ice nuclei: learning from the use of different kaolinite samples and different coatings, Atmos. Chem. Phys., 14, 55295546, doi:10.5194/acp-14-5529-2014, 2014.

Winker, D. M., Vaughan, M. A., Omar, A., Hu, Y., Powell, K. A., Liu, Z., Hunt, W. H., and Young, S. A.: Overview of the CALIPSO mission and CALIOP data processing algorithms, J. Atmos. Ocean. Tech., 26, 2310-2323, 2009. 